Prepared in cooperation with the Bureau of Reclamation

Patterns of Larval Sucker Emigration from the Sprague and Lower Williamson Rivers of the Upper Klamath Basin, Oregon, Prior to the Removal of Chiloquin Dam-2007/2008 Annual Report

Open-File Report 2011-1108 



\section{Patterns of Larval Sucker Emigration from the Sprague and Lower Williamson Rivers of the Upper Klamath Basin, Oregon, Prior to the Removal of Chiloquin Dam-2007/2008 Annual Report}

By Craig M. Ellsworth, David T. Banks, and Scott P. VanderKooi

Prepared in cooperation with the Bureau of Reclamation

Open-File Report 2011-1108

U.S. Department of the Interior U.S. Geological Survey 


\section{U.S. Department of the Interior \\ KEN SALAZAR, Secretary}

\section{U.S. Geological Survey \\ Marcia K. McNutt, Director}

U.S. Geological Survey, Reston, Virginia: 2011

For more information on the USGS-the Federal source for science about the Earth, its natural and living resources, natural hazards, and the environment, visit http://www.usgs.gov or call 1-888-ASK-USGS.

For an overview of USGS information products, including maps, imagery, and publications, visit http://www.usgs.gov/pubprod

To order this and other USGS information products, visit http://store.usgs.gov

Suggested citation:

Ellsworth, C.M., Banks, D.T., and VanderKooi, S.P., 2011, Patterns of larval sucker emigration from the Sprague and lower Williamson Rivers of the Upper Klamath Basin, Oregon, prior to the removal of Chiloquin Dam-2007/2008 annual report: U.S. Geological Survey Open-File Report 2011-1108, 30 p.

Any use of trade, product, or firm names is for descriptive purposes only and does not imply endorsement by the U.S. Government.

Although this report is in the public domain, permission must be secured from the individual copyright owners to reproduce any copyrighted material contained within this report. 


\section{Contents}

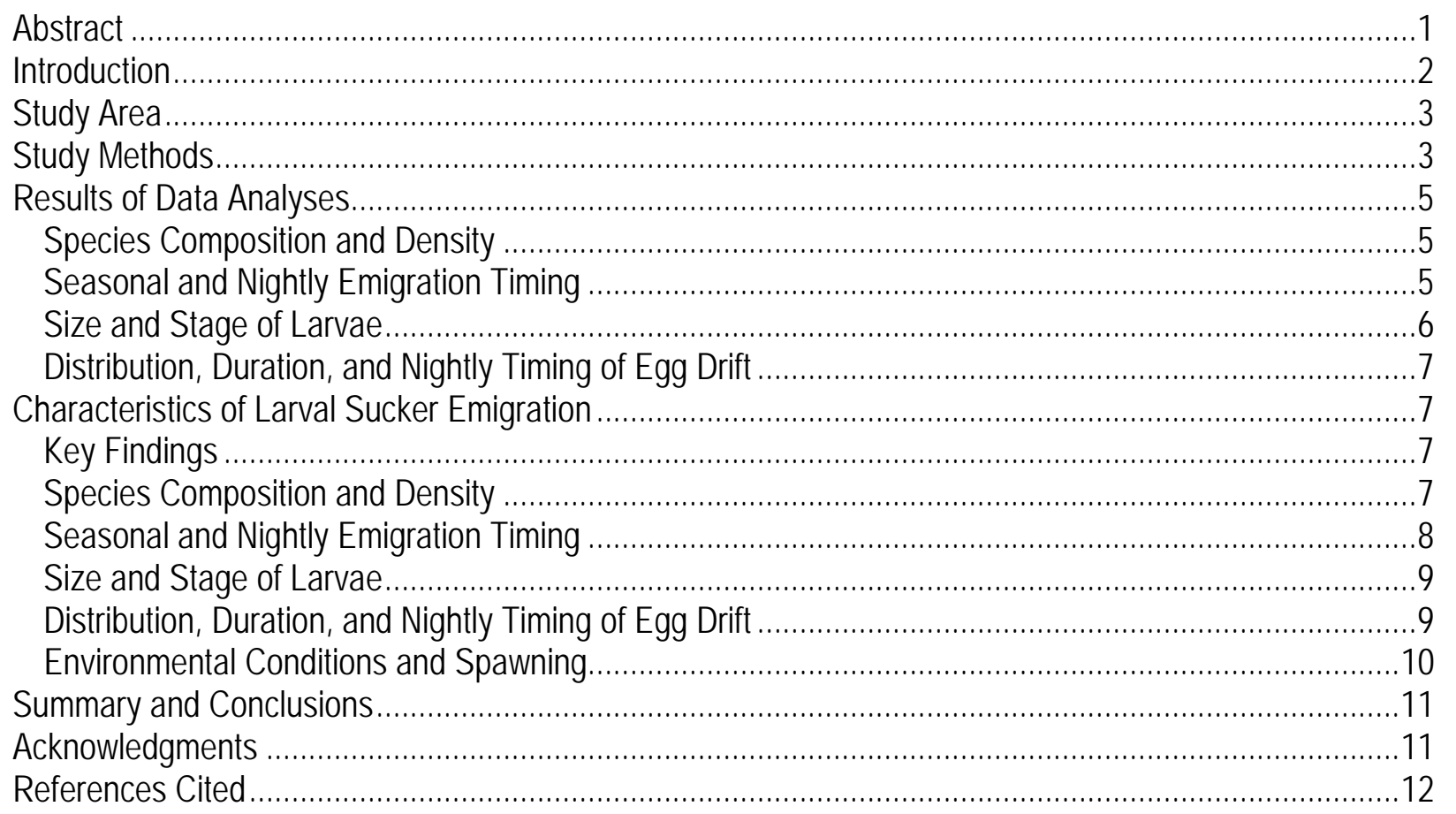




\section{Figures}

Figure 1. Map of the study area showing larval sucker sampling sites used in 2007 and 2008 to assess larval drift patterns of Lost River and shortnose suckers in the Sprague and Williamson Rivers, Oregon, prior to removal of Chiloquin Dam.

Figure 2. Natural log transformed nightly $( \pm S D)$ mean density of Lost River sucker (LRS) and shortnose sucker or Klamath largescale (SNS-KLS) larvae at (a) Power Station, (b) Chiloquin, and (c) Williamson sampling sites in 2007

Figure 3. Natural log transformed nightly $( \pm$ SD) mean density of Lost River sucker (LRS) and shortnose sucker or Klamath largescale (SNS-KLS) larvae at Power Station (a), Chiloquin (b), and Williamson (c) sampling sites in 2008

Figure 4. Cumulative proportion of shortnose and Klamath largescale sucker (SNS-KLS) and Lost River sucker (LRS) larvae captured at (a) Power Station, (b) Chiloquin, and (c) Williamson sampling sites by date in 2007 .

Figure 5. Cumulative proportion of shortnose and Klamath largescale sucker (SNS-KLS) and Lost River sucker (LRS) larvae captured at (a) Power Station, (b) Chiloquin, and (c) Williamson sampling sites by date in 2008 .

Figure 6. Cumulative degrees calculated from the mean daily temperature of the Sprague River near Chiloquin, OR beginning with the first detection of sucker eggs in the drift at Chiloquin sampling site by Julian date in 2007 and 2008.

Figure 7. Proportion of shortnose and Klamath largescale sucker (SNS-KLS) and Lost River sucker (LRS) larvae capture by sample hour at Power Station, Chiloquin, and Williamson sampling sites in 2007 .......... 20 Figure 8. Proportion of shortnose and Klamath largescale sucker (SNS-KLS) and Lost River sucker (LRS) larvae capture by sample hour at Power Station, Chiloquin, and Williamson sampling sites in 2008 ......... 21 Figure 9. Cumulative percentages of sucker eggs collected at Chiloquin sampling site by date in 2007 and 2008.

Figure 10. Sprague River temperature $\left(\mathrm{C}^{\circ}\right)$ and discharge $\left(\mathrm{m}^{3} / \mathrm{s}\right)$ and Upper Klamath Lake elevation $(\mathrm{ft} ; \mathrm{a})$, date of passage or detection of passive integrated transponder (PIT) tagged adult Klamath largescale (KLS), Lost River sucker (LRS), and shortnose sucker (SNS) past the Chiloquin Dam on the Sprague River (b; U.S. Geological Survey, unpub. data, 2007), and natural transformed mean nightly egg and larval densities at Chiloquin sampling site (c and d) in 2007. 23

Figure 11. Sprague River temperature $\left(\mathrm{C}^{\circ}\right)$ and discharge $\left(\mathrm{m}^{3} / \mathrm{s}\right)$ and Upper Klamath Lake elevation (ft; a), date of passage or detection of adult passive integrated transponder tagged Klamath largescale (KLS), Lost River sucker (LRS), and shortnose sucker (SNS) past the Chiloquin Dam on the Sprague River (b; Janney and others, 2009), and natural transformed mean nightly egg and larval densities at Chiloquin sampling site (c and d) in 2008

Figure 12. Proportions of sucker eggs collected in the drift by sample hour for the first seven hours after sunset at Chiloquin sampling site in 2007 and 2008 


\section{Tables}

Table 1. Total number of samples collected and number of sampling events for the period between the first and last capture, including zero catches, of shortnose and Klamath largescale sucker (SNS-KLS), Lost River sucker (LRS), and unidentified sucker (UIS) larvae in the Sprague and Williamson Rivers in 2007 and

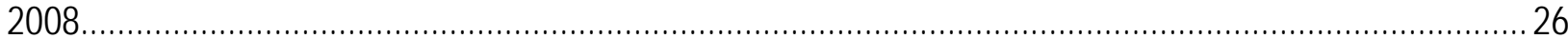

Table 2. Sampling schedule for larval drift sample sites in 2007 and 2008 .........................................26

Table 3. Mean larval densities (larvae $/ \mathrm{m}^{3}$ ) for drift samples collected during the period between the first and last capture of shortnose and Klamath largescale sucker (SNS-KLS), Lost River sucker (LRS), and unidentified sucker (UIS) larvae at sites on the Sprague and Williamson Rivers in 2007.

Table 4. Date, hour, and density (larvae/ $\mathrm{m}^{3}$ ) of peak catches of shortnose sucker-Klamath largescale (SNS-KLS) larvae and Lost River sucker (LRS) larvae at sample sites on the Sprague and Williamson Rivers in 2007 and 2008.

Table 5. Growth stages for shortnose and Klamath largescale sucker (SNS-KLS), Lost River sucker (LRS), and unidentified sucker (UIS) captured in the Williamson and Sprague Rivers in 2007 and 2008.

Table 6. Median standard length and the number of larvae $<9.0 \mathrm{~mm}$ and juveniles $>14.5 \mathrm{~mm}$ collected for shortnose and Klamath largescale sucker (SNS-KLS), Lost River sucker (LRS), and unidentified sucker (UIS) captured in 2007 and 2008.

Table 7. Total number of sucker eggs, average egg densities (eggs/ $\mathrm{m}^{3}$ ), and peak egg densities (eggs/ $\mathrm{m}^{3}$ ) for all sucker species combined for the period between the first and last capture, including zero catches, in 2007 and 2008 


\section{Conversion Factors}

\begin{tabular}{llll}
\multicolumn{1}{c}{ SI to Inch/Pound } & & & To obtain \\
\hline & Length & \\
\hline millimeter $(\mathrm{mm})$ & 0.03937 & inch (in.) & \\
meter $(\mathrm{m})$ & 3.281 & foot (ft) & \\
kilometer $(\mathrm{km})$ & 0.6214 & mile (mi) \\
\hline & Volume & \\
\hline cubic meter $\left(\mathrm{m}^{3}\right)$ & 35.31 & cubic foot $\left(\mathrm{ft}^{3}\right)$ \\
\hline
\end{tabular}

Temperature in degrees Celsius $\left({ }^{\circ} \mathrm{C}\right)$ may be converted to temperatures in degrees Fahrenheit $\left({ }^{\circ} \mathrm{F}\right)$ by using the equation:

$$
{ }^{\circ} \mathrm{F}=\left(1.8 \times{ }^{\circ} \mathrm{C}\right)+32 .
$$




\title{
Patterns of Larval Sucker Emigration from the Sprague and Lower Williamson Rivers of the Upper Klamath Basin, Oregon, Prior to the Removal of Chiloquin Dam-2007/2008 Annual Report
}

\author{
By Craig M. Ellsworth, David T. Banks, and Scott P. VanderKooi
}

\begin{abstract}
In 2007 and 2008, drift samples were collected from three sites on the lower Sprague and Williamson Rivers to assess emigration patterns of larval Lost River suckers (LRS) and shortnose suckers (SNS), to include characterization of the drift timing, relative abundance, and growth stage frequencies of larval suckers emigrating from the Sprague watershed prior to the removal of Chiloquin Dam. Chiloquin Dam was built on the lower Sprague River in 1914 to serve as a diversion structure to supply irrigation water for the Modoc Point Irrigation District. The dam was identified as a barrier that potentially inhibited or prevented the upstream spawning migrations and other movements of endangered LRS, SNS, and other fish in the Sprague River. These data will be used to evaluate changes in spawning distribution of LRS and SNS in the Sprague River following the dam's removal, which occurred in the fall of 2008. Drift samples were collected at two sites on the Sprague River, one upstream of the dam at rkm (river kilometer) 9.5 near the power substation at the intersection of Chiloquin Ridge Road and Sprague River Highway (Power Station) and the other downstream of the dam at river rkm 0.7 near the town of Chiloquin, Oregon (Chiloquin). Samples also were collected on the Williamson River at rkm 7.4 at the Modoc Point Road Bridge (Williamson), which is also downstream of the dam.

Data presented in this report were collected as part of a continuation of a research project that began in 2004. Larval drift parameters measured in 2007 and 2008 were similar to those measured from 2004 to 2006. Most larvae and eggs were collected at the two drift sample sites below Chiloquin Dam (Chiloquin at rkm 0.7 on the Sprague River and Williamson at rkm 7.4 on the Williamson River). Mean and peak sample densities increased with proximity to Upper Klamath Lake. Peak larval densities continued to be collected between one and three hours after sunset at Chiloquin, which is the drift site nearest a known spawning area. Catch distribution of larvae and eggs in the lower Sprague and Williamson Rivers continues to indicate that most of the spawning of SNS and LRS occurs below Chiloquin Dam. The sizes and growth stages indicate that larval emigration from spawning areas via drift occurs within a few days after their emergence from the spawning gravels. Larval suckers appear to move downstream quickly until they reach suitable rearing habitat.
\end{abstract}




\section{Introduction}

The upper Klamath Basin hosts several endemic fish species, two of which, the Lost River sucker Deltistes luxatus (LRS) and the shortnose sucker Chasmistes brevirostris (SNS), were listed as endangered under the Endangered Species Act in 1988 (U.S. Fish and Wildlife Service, 2008). Like other lakesuckers of western North America (e.g., cui-ui Chasmistes cujus and June sucker Chasmistes liorus), both LRS and SNS are described as being long-lived (up to 40 years) obligatory lake dwellers that typically use the primary tributaries of the lakes they inhabit for spawning (Koch, 1973; Scoppettone, 1988; Scoppettone and Vinyard, 1991; Modde and Muirhead, 1994; Cooperman and Markle, 2003). The Klamath largescale sucker Catostomus snyderi (KLS) is also an upper Klamath Basin endemic and has been identified by the U.S. Fish and Wildlife Service as a species of concern primarily because of its limited distribution (Oregon Natural Heritage Information Center, 2007). Klamath largescale suckers are believed to be more of a riverine species, although they also are found in Upper Klamath Lake (Moyle, 2002).

Prior to the federal listing of LRS and SNS, little empirical information existed regarding the distribution and extent of spawning areas used by these populations in the Sprague and Williamson Rivers. Recent research on spawning migrations of LRS, SNS, and KLS in the Sprague River watershed has identified apparent spawning locations in the lower Williamson River between rkm (river kilometer) 10.0 and 17.5 and in the Sprague River from its confluence with the Williamson River to Chiloquin Dam (rkm 0.0-1.3), the Nine Mile area (rkm 13.0-46.0), and Beatty Gap (rkm 112.0-120.0). A small number of radio tagged fish also were detected migrating into the Sycan River and the North Fork of the Sprague River (Ellsworth and others, 2007a; Ellsworth and others, 2007b; Tyler and others, 2007). There also appears to be some level of spatial and temporal separation in the spawning locations and timing between LRS, SNS, and KLS in the Sprague River drainage. These telemetry data, as well as concurrently collected larval drift data, indicate that most KLS spawn in the upper reaches of the Sprague River (rkm 100120) early in the spring (March-April), whereas SNS spawn primarily in the lower Sprague (rkm 0-10) and Williamson (rkm 10-17) rivers later in the spring (April-May). These same telemetry and larval drift data show that spawning areas used by LRS generally overlap those areas used by both KLS and SNS, but LRS generally spawn earlier than KLS in the upper reaches of the Sprague River and earlier than SNS in the lower reaches of the Sprague and Williamson Rivers.

Data presented in this report is a summary of larval drift collection efforts for 2007 and 2008. These data are part of a multi-year study by the U.S. Geological Survey, Klamath Falls Field Station to characterize the drift timing, spawning area distribution, relative abundance, and growth stage frequencies of larval suckers emigrating from the Sprague River drainage basin before and after the removal of Chiloquin Dam. This report was funded by the Bureau of Reclamation U.S. Department of Interior (Interagency Agreement 06AA204054 and 07AA200144) and the U.S. Geological Survey. Funding was provided by Reclamation as part of its mission to manage, develop, and protect water and related resources in an environmentally and economically sound manner in the interest of the American public. This study was conducted concurrently with several other studies that involved the monitoring of adult sucker movements in the Sprague and Williamson Rivers during their spawning seasons (see Ellsworth and others, 2007a; Ellsworth and others, 2007b; Tyler and others, 2007; Janney and others, 2008). The collection and analyses of these data will provide resource managers an opportunity to compare the spawning distributions of suckers in the Sprague and Williamson Rivers before 
and after the removal of Chiloquin Dam and to determine the effectiveness of dam removal as a means to improve passage for endangered suckers to underutilized spawning areas in the Sprague River.

\section{Study Area}

The Sprague River originates to the east of Upper Klamath Lake in the Gearhart and Quartz mountains in southeastern Oregon, and drains an area of approximately 4,092 $\mathrm{km}^{2}$ (fig. 1). The lower $140 \mathrm{~km}$ of the Sprague River is a low gradient stream (approximately $0.4 \mathrm{~m} / \mathrm{km}$ ) and is characterized by broad valleys with extensive riverine meanders interspaced with low canyons or gaps created by uplifts or block faulting geology. Associated with these uplifted areas is an upwelling of groundwater that discharges to the Sprague River as it cuts through these formations (Gannett and others, 2007). The Sprague River is the principal tributary of the Williamson River, which also originates east of Upper Klamath Lake in the Yamsay Mountains. The combined flow of the Williamson and Sprague Rivers provides approximately 50 percent of the annual inflow to Upper Klamath Lake (Kann and Walker, 2001). The hydrographs for both rivers typically are dominated by a late winter to early spring snowmelt peak followed by low base flows during summer and fall.

Chiloquin Dam was located at rkm 1.3 on the Sprague River and approximately $19.0 \mathrm{rkm}$ upstream from Upper Klamath Lake. The approximately 3.4- m high, 58.0- $\mathrm{m}$ wide dam was constructed to serve as a diversion structure to supply irrigation water for the Modoc Point Irrigation District. In 2000, the USGS implemented a sampling program at the Chiloquin Dam fish ladder to monitor the composition, timing, and relative abundance of spring spawning runs of suckers in the Sprague River as part of a larger effort to monitor LRS and SNS populations in the Upper Klamath Basin (Shively and others, 2001). Regular sampling showed that the number of suckers entering the fish ladder was highly variable among years. Some movement of KLS, LRS, and SNS through the Chiloquin Dam fish ladder was documented during their respective spawning seasons, but the dam was identified as a significant barrier to fish migration on the Sprague River, and in some years likely prevented the upstream spawning migrations of these and other migratory fish species entering the Sprague River (National Research Council, 2003; U.S. Fish and Wildlife Service, 2008).

\section{Study Methods}

Drifting larval suckers and eggs were collected in the lower Sprague and Williamson Rivers at three sites in 2007 and 2008 (fig. 1). Sampling sites were selected from available bridge crossings that facilitated collection of samples from the river at the thalweg and provided representation of larval sucker emigration from known and suspected spawning areas in the lower watershed. The Williamson River was sampled at Modoc Point Road ("Williamson” in fig. 1; rkm 7.4) and the Sprague River was sampled at a private bridge in Chiloquin, Oregon (“Chiloquin"; rkm 0.7) and at Chiloquin Ridge/USFS 5810 Road near Chiloquin ("Power Station”; rkm 9.5).

Sampling at all locations began on March 11, 2007 and on March 30, 2008. Both dates were prior to the detection of most suckers migrating past the Williamson River fish weir at rkm 10.0 (U.S. Geological Survey, unpub. data, 2007-08). In 2007, sampling concluded at all locations on June 30. In 2008, sampling concluded on June 29 at Power Station, on July 2 at 
Chiloquin, and on July 10 at Williamson. Sampling during both years ended after the number of larvae being collected had declined to just a few individuals per night and no new spawning activity had been observed for more than 4 weeks.

Drift samples were collected three times a week - on Sunday, Tuesday, and Thursday nights - resulting in a total of 1,589 samples in 2007 and 1,351 samples in 2008 (table 1). Samples were collected by two technicians; one collecting samples every half hour at one site and the other collecting hourly samples alternating between the other two sites. This sampling schedule was rotated on a nightly basis so each site was sampled on a half-hourly basis once per week. Samples were collected between 0.5 hours before sunset and 8.0 hours after sunset throughout the larval drift period (table 2).

Modified plankton nets $2.5 \mathrm{~m}$ in length with a $0.3 \mathrm{~m}$ diameter circular opening were used to collect the samples. Nets were constructed of $800 \mu \mathrm{m}$ Nitex ${ }^{\circledR}$ mesh and were fitted with a removable collection cup with $500 \mu \mathrm{m}$ Nitex ${ }^{\circledR}$ mesh windows. A General Oceanics Model 2030R flow meter with a standard rotor was used to record water velocities at the mouth of the net at sites where water velocities were great enough to keep the net suspended in the water column. At the Williamson site, where water velocities were not great enough to keep the net suspended in the water column, the net was modified with a PVC hoop fixed to the net opening to keep the net from collapsing around the flow meter, and a polystyrene float was fixed to the collection cup to keep the net horizontal in the water column. A General Oceanics Model 2030R6 flow meter with a low-velocity rotor was used to record water velocities at this site. A 6$\mathrm{mm}$ rope was attached to one side of a stainless steel ring fitted into the opening of the net to permit it to be deployed and retrieved from bridges at all sites. A pancake-shaped weight (either 3.6 or $4.5 \mathrm{~kg}$ depending on water velocity) was attached to the opposite side of the ring to hold the net opening perpendicular to the river flow. Drift samples were collected in the thalweg for 10 minutes from the downstream side of each bridge.

Following the retrieval of a drift net, any larvae or debris impinged on the sides of the net was rinsed into the collection cup with a portable water sprayer. Larvae and debris were then transferred into sample bottles and preserved in 10 percent formalin. Fish specimens were sorted from sample debris within 24 hours of collection. Fish specimens were then enumerated, stored in 95\% ethanol, and delivered to Oregon State University for identification and measurement. Larvae were identified under magnification (2 to 10x) to the lowest possible taxonomic level using a key for larval fishes of the Upper Klamath Basin (Written communication, D. Simon, Oregon State University, March 12, 2004). Larval sucker species identification was based primarily on differences in pigmentation (dorsal melanophores), which generally allows for separation of LRS larvae from SNS and KLS larvae. Because the pigmentation patterns between SNS and KLS are similar, we were unable to positively identify larvae of either of these species; therefore, larvae identified as either SNS or KLS were combined and designated as SNS-KLS for this report. Larval suckers exhibiting intermediate characteristics used to separate LRS larvae from SNS-KLS larvae were designated as unidentified sucker larvae (UIS). Larvae that were damaged to the extent that identification could not be made also were designated as UIS. Developmental stage was determined by the degree of caudal fin development, and individuals were categorized into preflexion, flexion, and postflexion groups. Individuals designated with an undetermined growth stage were typically damaged in a way that prevented the determination of growth stage. Notochord length was measured for preflexion larvae while standard length was measured for flexion and postflexion larvae and juvenile suckers. Median larval sucker lengths were calculated using both standard length and notochord length measurements. In drift samples 
in which the number of larvae exceeded 50 individuals, a subsample consisting of 25 of each species or species complex was measured for length. Selected juvenile suckers collected in 2007 and 2008 were X-rayed to determine species or species complex using an identification method based on vertebral counts (Markle and others, 2005) because an identification key based on phenotypical characteristics does not yet exist for these early life history stages. We could not use lip morphology or gill raker counts to distinguish SNS from KLS for most individuals due to the small size of most of the fish selected for vertebral counts.

Mean densities of LRS, SNS-KLS, and UIS larvae and eggs for samples collected between the first and last capture were used to compare capture densities among sites. A natural log-transformation was made to the nightly mean larval densities to better visualize seasonal larval drift trends. Cumulative percentages of eggs and larvae captured over time were calculated to present differences in seasonal drift timing between eggs and larval LRS and SNS-KLS. Larval sucker and egg catches were expressed as the number of larvae or eggs per unit volume (larvae or eggs $/ \mathrm{m}^{3}$ ) for summaries of and comparisons among sample sites. Discharge and temperature data for 2007 and 2008 were obtained from the Sprague River gaging station near Chiloquin at rkm 8.7 (USGS Station No. 11501000) and from the Williamson River gaging station at rkm 16.6 (USGS Station No. 11502500). Degree days for egg incubation and larval drift in the Sprague River were determined by calculating the cumulative mean daily water temperature as measured at the Sprague River gaging station beginning with the first detection of eggs in the drift at the Chiloquin sampling site.

\section{Results of Data Analyses}

\section{Species Composition and Density}

Drift samples containing both LRS and SNS-KLS larvae were collected at all three sampling sites in 2007 and 2008. Mean and peak larval densities for both LRS and SNS-KLS larvae were two orders of magnitude higher at the two sampling sites downstream of Chiloquin Dam (Chiloquin and Williamson) than at the sampling site upstream of the dam (Power Station) (tables 3 and 4). The dominant species in the larval catch at the two sites downstream of the dam switched between years, with the larval catch being dominated by LRS in 2007 and SNS-KLS in 2008.

\section{Seasonal and Nightly Emigration Timing}

Larval drift generally occurred over a 4- to 6- week period with the collection of larvae beginning in early April at Power Station and mid- to late May at Chiloquin and Williamson (figs. 2 and 3). The latest larval catches were at Williamson, with catches extending into early July. Plots of the mean nightly densities (figs. 2 and 3) as well as the cumulative catch curves (figs. 4 and 5) show that the seasonal drift period at Power Station typically occurred earlier than at either Chiloquin or Williamson, which occurred virtually simultaneously. In 2007, however, a small second peak in LRS drift at Power Station occurred nearly simultaneously with the peak LRS drift below Chiloquin Dam (figs. 4a and 4b). 
The cumulative catch curves at the two drift sites downstream of Chiloquin Dam show that LRS larvae typically drifted earlier in the season than SNS-KLS larval at these sites (figs. 4b and 4c; 5b and 5c). These figures also show that the drift of both LRS and SNS-KLS larvae occurred earlier in 2007 than in 2008. Peak larval drift downstream of Chiloquin Dam occurred 11 days earlier for LRS and 27 days earlier for SNS-KLS in 2007.

Cumulative degree days for the Sprague River followed a similar pattern during the periods of egg and larval drift in both 2007 and 2008. The most notable difference between years was a temperature lag of 11 to 15 days in 2008 (fig. 6). Cumulative degree days between the first detection of eggs and peak larval drift for both species were greater in 2007 than in 2008. Cumulative degree days to peak LRS catches were $26.6^{\circ} \mathrm{C}$ more in 2007 than in 2008, while cumulative degree days to peak SNS-KLS catches were $208.4^{\circ} \mathrm{C}$ more in 2008 than in 2007. The higher measurement of degree days for SNS-KLS larvae was due primarily to the large difference in drift timing between years (fig. 6). However, mean water temperatures between the first detection of eggs and peak larval drift for both species were higher in 2008 than 2007. Mean water temperatures between peak egg and LRS larval drift were $11.80 \mathrm{C}$ in 2007 and $12.4^{\circ} \mathrm{C}$ in 2008, and between peak egg and SNS-KLS drift were $13.7^{\circ} \mathrm{C}$ in 2007 and $14.3^{\circ} \mathrm{C}$ in 2008 .

Nightly peaks in larval emigration were again discernible at both Chiloquin and Williamson (figs. 7 and 8). The timing of nightly peaks appeared to vary between sites, with larvae drifting later in the night as the distance between sample location and the nearest known spawning area increased. Larval drift at Chiloquin, the site closest to a known spawning area, generally peaked 1 to 3 hours after sunset, whereas larval drift at Williamson, a site farther from known spawning areas, peaked 6 to 8 hours after sunset. Low catches at Power Station made it difficult to distinguish a nightly peak in larval emigration.

\section{Size and Stage of Larvae}

Most of the larvae collected from the drift in 2007 and 2008 were in the flexion growth stage (table 5), and between 9.0 and $14.5 \mathrm{~mm}$ long. The median length of larvae collected at Power Station was greater than that of larvae collected at Chiloquin or Williamson for both 2007 and 2008 (table 6). The larvae collected at Chiloquin generally were at the same growth stage and were within $0.2 \mathrm{~mm}$ of the median length of larvae collected at Williamson in both years. There was a decrease of between 0.7 and $1.0 \mathrm{~mm}$ in the measured median length of both LRS and KLS larvae at Williamson and Chiloquin from 2007 to 2008.

Most of the larval suckers less than $9.0 \mathrm{~mm}$ were collected at Chiloquin in both 2007 and 2008. Larvae and juveniles greater than $14.5 \mathrm{~mm}$ were collected at all sites but again most were collected at Chiloquin. Eight juvenile suckers collected at Chiloquin in 2007 were large enough to be x-rayed and identified by vertebral counts. All eight of these fish were identified as most likely being KLS. The numbers of juveniles collected in 2008 increased substantially over 2007 and 192 juveniles were selected for x-ray identification. Of these fish, 69 were identified as LRS, 50 as SNS-KLS, and 73 either had identification characteristics indistinguishable between the two species complexes or the vertebrae were not developed enough to accurately use this identification method. 


\section{Distribution, Duration, and Nightly Timing of Egg Drift}

Sucker eggs were collected from all sample locations in 2007 and 2008, but most eggs were collected at Chiloquin in both years (table 7). Egg drift at Chiloquin occurred earlier and over a shorter period of time in 2007 than in 2008. Eggs were collected between April 1 to June 5, 2007 and from April 15 to July 1, 2008 (fig. 9). A bimodal peak in egg drift was observed at Chiloquin in 2007 with a smaller peak occurring on April 10 and a larger peak occurring on April 29 (fig. 10c). Only a single peak in egg drift was observed at Chiloquin in 2008 (fig. 11c). A relatively sustained decline in water temperature was observed between the two peaks in egg drift in 2007 (fig. 10) whereas water temperatures during egg drift in 2008 generally were on a rising trend (fig. 11). Mean water temperatures between the first detection of eggs in the drift (April 1, 2007 and April 15, 2008) and peak egg drift (April 29, 2007 and May 3, 2008) were $11.0^{\circ} \mathrm{C}$ in 2007 and $9.4^{\circ} \mathrm{C}$ in 2008 . Mean and peak egg densities were similar between 2007 and 2008. Peak egg collection during our nightly sampling period typically occurred early in the evening during the first and second sampling efforts of the night (fig. 12). Egg catches were insufficient at Power Station and Williamson to detect any nightly patterns in either year.

\section{Characteristics of Larval Sucker Emigration}

\section{Key Findings}

Data collected in 2007 and 2008 indicate that spawning of LRS, KLS, and possibly SNS continued to occur both upstream and downstream of Chiloquin Dam as identified in the earlier phases of this study. Larval LRS and SNS-KLS densities continued to be substantially higher at the two sampling sites downstream of Chiloquin Dam than at the sampling site upstream of the dam, and larval densities were found to increase with proximity to Upper Klamath Lake. Most larvae recovered from the drift samples were in the flexion growth stage and were between 9.0 and $14.5 \mathrm{~mm}$ in length. The few larvae collected upstream of the dam were longer on average than those collected downstream of the dam. Juvenile LRS, KLS, and possibly SNS were collected in the Sprague and Williamson Rivers indicating that there is some degree of in-river rearing for these species. Larval drift begins prior to sunset and peaks shortly after sunset. The timing of the nightly peak larval drift at any particular sample site appears to be correlated with the distance between the nearest upstream spawning area and that sample site. Egg drift downstream of Chiloquin Dam occurs primarily when catches of LRS and SNS are highest in the Chiloquin Dam fish ladder.

\section{Species Composition and Density}

Larvae identified as both LRS and SNS-KLS were collected from all three sampling sites indicating that spawning for LRS and either KLS or SNS (or both) is occurring upstream and downstream of Chiloquin Dam. A concurrent radio telemetry study found that most tagged KLS and some tagged LRS migrated to several relatively discrete spawning areas in the upper reaches of the watershed whereas most tagged LRS and most tagged SNS remained in the lower Sprague and Williamson Rivers downstream of Chiloquin Dam (Ellsworth and others, 2007a; Ellsworth and others, 2007b; Tyler and others, 2007). Larval densities measured at the three sample sites in 
the lower Sprague and Williamson Rivers indicate that most of the spawning activity in this reach is occurring downstream of the dam. Although there appears to be suitable spawning habitat between Power Station and the bottom of Chiloquin Narrows, there has been little indication that any spawning is occurring in this reach of the Sprague River.

We detected what appears to be some interannual variation in larval densities in the lower Sprague and Williamson Rivers in 2007 and 2008. The dominant species in the larval catch switched between the two sample years, with larval catches being dominated by LRS in 2007 and by SNS-KLS in 2008. When compared to previous years, mean sample densities of larval LRS were higher in 2007 but lower in 2008 (Ellsworth and others, 2008, 2009). Sample densities of SNS-KLS at the Chiloquin and Williamson sampling sites in 2007 and 2008 were similar to densities measured in previous years. Mean larval densities increased in a downstream direction in 2007 and 2008, presumably with the addition and concentration of larvae as they migrate out of the lower Sprague and Williamson Rivers to Upper Klamath Lake.

\section{Seasonal and Nightly Emigration Timing}

Seasonal and nightly patterns in the onset, magnitude, timing, and duration of larval drift similar to those seen in 2004 to 2006 continued to be observed in 2007 and 2008. As noted in previous years, larval drift at Power Station continued to begin earlier than larval drift at Chiloquin or Williamson. In 2007 and 2008, LRS and SNS-KLS larvae were collected at Power Station primarily from early April to early May, whereas drift at Chiloquin and Williamson occurred from mid-May to early July. This temporal separation in larval drift appears to support the possibility of multiple spawning groups of suckers in the Sprague River, with KLS and a group of LRS spawning in its upper reaches earlier in the spring and SNS and a group of LRS spawning in its lower reaches later in the spring (see Ellsworth and others, 2007a; Ellsworth and others, 2007b). The bimodal peak in LRS drift at Power Station in 2007 with the second peak occurring at the same time as the LRS drift downstream of Chiloquin Dam suggests there may have been some level of spawning activity by LRS upstream of the dam at approximately the same time LRS were spawning downstream of the dam.

Distinct nightly emigration patterns were observed at Chiloquin and Williamson in both 2007 and 2008. As in samples collected from 2004 to 2006, both LRS and SNS-KLS larvae appeared to initiate drift shortly before sunset. Peak larval drift for LRS and SNS-KLS at Chiloquin occurred from 1 to 3 hours after sunset, with SNS-KLS drift typically extending later into the evening than LRS drift. In contrast, peak larval drift at Williamson occurred from 6 to 8 hours after sunset for both LRS and SNS-KLS. This indicates there is a time lag between the initiation of drift and when larvae actually arrive at this site on the Williamson River. This time lag probably is due to the distance between this site and where larvae are beginning their nightly drift. No distinctive nightly drift pattern was evident at Power Station in either 2007 or 2008.

Interannual variation in the seasonal timing of SNS-KLS drift was observed downstream of Chiloquin Dam. Peak SNS-KLS drift at Chiloquin occurred 27 days later in 2008 than in 2007, resulting in a greater temporal separation from the peak LRS drift in 2008. The source of the late drift of SNS-KLS larvae in 2008 is uncertain as there were no substantial increases in SNS or KLS detections in the Chiloquin Dam fish ladder or on the PIT (Passive Integrated Transponder) tag arrays located downstream of the dam and no second peak in egg drift prior to this peak larval drift. 


\section{Size and Stage of Larvae}

Larval LRS and SNS-KLS appear to be most active in the drift at the flexion growth stage. Individuals in other developmental stages were also collected in 2007 and 2008, suggesting that younger and older fish also were present in the system but were less likely to be collected with our sampling equipment. The collection of preflexion larvae, primarily at Chiloquin, may be an indication that larvae are being flushed from the interstitial spaces in the gravel before they are physiologically ready to drift. The collection of postflexion larvae and juveniles, again primarily at Chiloquin, may be due in part to the hydraulics at these sites being more likely to sweep fish that would not typically be found in the drift into our sampling gear. The collection of more developed larvae and juveniles in the Sprague and Williamson Rivers continues to indicate that there may be some level of in-river rearing for KLS, LRS, and possibly SNS in the Sprague River drainage.

A combination of warmer water temperatures at the beginning of the spawning period and lower flows during the larval drift period in 2007 could have led to the greater median larval lengths observed that year. Warmer water temperatures may have led to faster development, an earlier emergence, and a larger median larval length at the initiation of drift. Lower discharges could have reduced the scouring of younger larvae from the spawning substrate and slowed transport time between spawning areas and our sample locations, thus allowing more time for growth. Both of these scenarios could explain our observations for LRS larvae in both years, but not for SNS-KLS larvae. Although mean daily discharges during the 2 weeks prior to peak SNSKLS drift were higher in 2008 than in 2007, mean daily water temperatures in the Sprague River during this period also were warmer than in 2007. Because SNS-KLS spawned in 2008 probably experienced warmer temperatures during incubation and emigration, it follows that they should have grown faster than those spawned in 2007. The greater mean lengths observed in 2007, however, indicate that the size of larvae in our samples is not controlled solely by temperature and that other factors, such as discharge or spawning location, also may be involved.

\section{Distribution, Duration, and Nightly Timing of Egg Drift}

Egg drift continued to occur primarily at Chiloquin when adult LRS and SNS were migrating into the Chiloquin Dam fish ladder. In contrast, there was little to no egg drift when adult KLS were migrating through the fish ladder in either year. This may be an indication that either KLS do not spawn in the reach downstream of Chiloquin Dam or that their eggs are less likely to be collected in the drift than LRS or SNS eggs. The timing of egg drift compared with the run timing of adult LRS and SNS at the Chiloquin Dam fish ladder in 2007 suggests that the first peak may have been mostly LRS eggs and the second peak mostly SNS eggs. Confirming this, however, is not possible because eggs from these species are currently indistinguishable. This bimodal peak in egg drift also may have been the result of a corresponding downward trend in water temperature extending over a 2-week period. Lower temperatures may have led to a temporary decrease in spawning activity, thus fewer eggs were available to drift. 
In 2008, we only saw one peak in egg drift at Chiloquin, which was followed 17 days later by a peak in LRS larvae and a peak in SNS-KLS larvae 52 days later. The timing of the SNS-KLS drift so late after egg drift suggests that eggs from SNS spawners were not detected at Chiloquin in 2008. This could be due to a number of factors including differences in flow or SNS spawning behavior between years that reduced egg drift or our ability to collect eggs in 2008 or that SNS eggs are less likely to drift or be detected in the drift than LRS eggs.

The removal of Chiloquin Dam is expected improve spawning conditions for LRS and SNS in the lower Sprague River (National Research Council, 2003). Most eggs are collected at Chiloquin, which is likely due to the sample site's proximity to spawning areas in the lower Sprague River. Egg drift for LRS and SNS is likely undesirable because eggs caught up in the drift probably will settle out into areas of the river with less than ideal conditions for incubation. The high incidence of egg drift at Chiloquin may be an indication of crowding downstream of the dam during the spawning season and the result of fish spawning over incubating eggs. Egg drift also may be an indication of fish spawning over armored substrate between this sample site and Chiloquin Dam (Coleman and others, 1989). Buettner and Scoppettone (1990) noted that LRS and SNS spawning over gravel would typically bury eggs within the top several centimeters of gravel. They noted that when spawning occurred over cobble and armored substrate, eggs fell into crevices or were swept downstream in the drift. Dam removal will allow improved access to upstream spawning areas and should reduce crowding in the lower Sprague River. Dam removal also should allow gravel and other coarse substrates to be transported into the armored spawning areas downstream of the dam site, which may increase available spawning substrate and decrease egg drift in this reach.

\section{Environmental Conditions and Spawning}

Differences in environmental conditions such as water temperature and river discharge between 2007 and 2008 likely affected the timing and duration of the LRS and SNS spawning migrations in the Sprague and Williamson Rivers. This in turn may have influenced some of the interannual differences in egg and larval densities described above. Low precipitation led to below average flows and an early peak discharge in the Sprague River during the 2007 spawning season. Precipitation in the Klamath Basin through June 2007 was only 84 percent of average (1971-2000) for the water year, and flows into Upper Klamath Lake were only 52 percent of average for the same time period. The peak discharge for the Sprague River in 2007 occurred in mid-March, which was 2 weeks earlier than average (Natural Resources Conservation Service, 2007). Precipitation in 2008 was more representative of an above average water year, with precipitation levels through June being 127 percent of average for the water year. The spring hydrologic peak for the Sprague River in 2008 occurred in mid April, 3 weeks later than average, and was followed by a late spring peak in early June (Natural Resources Conservation Service, 2008).

The timing of sucker spawning runs in the Sprague and Williamson Rivers has been correlated to water temperatures, with $10^{\circ} \mathrm{C}$ as an approximate threshold for cueing upstream migrations for most of these fish (Janney and others, 2009). Warmer water temperatures earlier in 2007 than in 2008 may have been a factor in the earlier detections of suckers at the Chiloquin Dam fish ladder in 2007. Earlier migrations of suckers in 2007 then corresponded with the earlier egg and larval drift observed in that year when compared to 2008. 


\section{Summary and Conclusions}

Larval drift was measured to determine if the spawning distributions of endangered suckers in the Sprague and Williamson rivers shifts following the removal of Chiloquin Dam. Pre-dam removal drift samples were collected at one site upstream and two sites downstream of the dam in 2007 and 2008. The highest densities of drifting larvae were detected at the two drift sample sites downstream of Chiloquin Dam. Very few larvae and eggs were collected at the sampling site upstream of the dam, indicating that spawning was limited in the reach immediately upstream of this site. Larval densities increased in a downstream direction in both 2007 and 2008, with the highest larval densities occurring at the sampling site nearest Upper Klamath Lake. Seasonal drift timing occurred earlier at Power Station (upstream of the dam) than at Chiloquin or Williamson (downstream of the dam). This is an indication that there continues to be some level of temporal separation between fish spawning in the upper and lower reaches of the Sprague River.

In 2007, a small number of LRS larvae were collected in the drift upstream of the dam at the same time that most LRS larvae were drifting from spawning areas downstream of the dam. This is an indication that a portion of the LRS group that spawns in the lower Sprague River may have been able to negotiate the Chiloquin Dam fish ladder and spawn upstream of the dam. The densities and hourly timing of larvae collected upstream of the dam indicate, however, that either spawning occurred some distance upstream or that production was very low immediately upstream of this site. There also appears to be some level of temporal separation of spawning between species, with LRS larvae typically drifting before SNS-KLS. Larval drift at Chiloquin, the site nearest to a known spawning area, began before sunset, with peak drift occurring 1 to 3 hours after sunset. Peak drift at Williamson, a site farther from a known spawning area, occurred 6 to 8 hours after sunset. Environmental conditions, such as water temperature, timing and duration of runoff, and magnitude of river discharge, likely contributed to observed differences in spawning run timing, egg drift, and larval drift among years. Finally, it should be noted that this report regarding larval drift of LRS and SNS-KLS larvae in the Sprague and Williamson Rivers is the last report prior to removal of the Chiloquin Dam, which occurred in August 2008.

\section{Acknowledgments}

We thank several USGS field personnel for collecting and processing field data (Jon Baldwin, Kevin Donner, Patrick Mirick, and Jack Tuomikoski in 2007 and Ernest Chen, Nathan Harris, Sierra Lewis, Jason Luginbill, and Jody Pope in 2008) and other USGS staff for reviewing and editing this manuscript. We also thank Doug Markle, Dave Simon, and other Oregon State University staff for processing laboratory data. Fish samples were obtained under Endangered Species permit TE007907 issued by the U.S. Fish and Wildlife Service and under scientific taking permits OR2007-3844 and OR2008-4462 issued by the Oregon Department of Fish and Wildlife. 


\section{References Cited}

Buettner, M., and Scoppettone, G., 1990, Life history and status of catostomids in Upper Klamath Lake, Oregon: U.S. Fish and Wildlife Service completion report, 108 p.

Coleman, M.E., Falter, M.A., and Scoppettone, G.G., 1989, Ecological investigations of catostomids from the Upper Klamath Lake Basin, Oregon: U.S. Fish and Wildlife Service completion report, $52 \mathrm{p}$.

Cooperman, M., and Markle, D.F., 2003, Rapid out-migration of Lost River and shortnose sucker larvae from in-river spawning beds to in-lake rearing grounds: Transactions of the American Fisheries Society, v. 132, p. 1138-1153.

Ellsworth, C.M., Tyler, T.J., Lutton, C.D., VanderKooi, S.P., and Shively, R.S., 2007a, Spawning migration movements of Klamath largescale, Lost River, shortnose suckers in the Williamson and Sprague Rivers, Oregon, prior to the removal of Chiloquin Dam-Annual Report 2005: Annual report of research to the Bureau of Reclamation, 42 p., Contract \# 01AA200026.

Ellsworth, C.M., Tyler, T.J., VanderKooi, S.P., and Shively, R.S., 2007b, Spawning migration movements of Klamath largescale, Lost River, shortnose suckers in the Williamson and Sprague Rivers, Oregon, prior to the removal of Chiloquin Dam-Report 2006: Annual report of research to the Bureau of Reclamation, 51 p., Contract \# 01AA200026.

Ellsworth, C.M., Tyler, T.J., VanderKooi, S.P., and Markle, D.F., 2008, Patterns of larval catostomid emigration from the Sprague and lower Williamson Rivers of the Upper Klamath Basin, Oregon, prior to the removal of Chiloquin Dam-2004-2005 Annual Report: Annual report of research to the Bureau of Reclamation, 45 p., Contract \# 06AA204054.

Ellsworth, C.M., Tyler, T.J., VanderKooi, S.P., and Markle, D.F., 2009, Patterns of larval sucker emigration from the Sprague and lower Williamson Rivers of the Upper Klamath Basin, Oregon, prior to the removal of Chiloquin Dam—2006 annual report: U.S. Geological Survey Open-File Report 2009-1027, 32 p.

Gannett, M.W., Lite, Jr., K.E., La Marche, J.L., Fisher, B.J., and Polette, D.J., 2007, Groundwater hydrology of the upper Klamath Basin, Oregon and California: U.S. Geological Survey Scientific Investigations Report 2007-5050.

Janney, E.C., Hayes, B.C., Hewitt, D.A., Barry, P.M., Scott, A.C., Koller, J.P., Johnson, M.A., and Blackwood, G., 2009, Demographics and 2008 run timing of adult Lost River (Deltistes luxatus) and shortnose (Chasmistes brevirostris) suckers in Upper Klamath Lake, Oregon, 2008: U.S. Geological Survey Open-File Report 2009-1183, 32 p.

Janney, E.C., Shively, R.S., Hayes, B.S., Barry, P.M., and Perkins, D., 2008, Demographic analysis of Lost River sucker and shortnose sucker populations in Upper Klamath Lake, Oregon: Transactions of the American Fisheries Society, v. 137, p. 1812-1825.

Kann, J., and Walker, W.W., 2001, Nutrient and hydrologic loading to Upper Klamath Lake, Oregon, 1991-1998: Prepared for the Bureau of Reclamation, Klamath Falls, Oregon, 114 p.

Koch, D.L., 1973, Reproductive characteristics of the cui-ui lakesucker (Chasmistes cujus Cope) and its spawning behavior in Pyramid Lake, Nevada: Transactions of the American Fisheries Society, v. 102, p. 145-149.

Markle, D.F., Cavalluzzi, M.R., and Simon, D.C., 2005, Morphology and taxonomy of Klamath Basin suckers (Catostomidae): Western North American Naturalist, v. 65, p. 473-489.

Modde, T., and Muirhead, N., 1994, Spawning chronology and larval emergence of June sucker (Chasmistes liorus): Great Basin Naturalist, v. 54, p. 366-370. 
Moyle, P.B., 2002, Inland fishes of California: Berkeley and Los Angeles, California, University of California Press, 502 p.

National Research Council, 2003, Endangered and threatened fishes in the Klamath River Basin: Causes of decline and strategies for recovery: Washington, DC, National Academy Press, 398 p.

Natural Resources Conservation Service, 2007, Oregon State Basin Outlook Report for June 2007: http://www.wcc.nrcs.usda.gov/cgibin/bor2.pl?state=or\&year=2007\&month =6\&format=text August 26, 2008.

Natural Resources Conservation Service, 2008, Oregon State Basin Outlook Report for June 2008: http://www.wcc.nrcs.usda.gov/cgibin/bor2.pl?state=or\&year=2007\&month =6\&format=text August 26, 2008.

Oregon Natural Heritage Information Center, 2007, Rare, threatened and endangered species of Oregon: Oregon Natural Heritage Information Center, Oregon State University, Portland, Oregon, $100 \mathrm{p}$.

Scoppettone, G.G., 1988, Growth and longevity of the cui-ui and longevity of other catostomids and cyprinids in western North America: Transactions of the American Fisheries Society, v. 117, p. 301-307.

Scoppettone, G.G., and Vinyard, G., 1991, Life history and management of four endangered lacustrine sucker, in Minckley, W.L., and Deacon, J.E., eds., Battle against extinction: native fish management in the American West: University of Arizona Press, Tucson, Arizona, p. 359377.

Shively, R.S., Neuman, E.B., Cunningham, M.E., and Hayes, B.S., 2001, Monitoring of Lost River and shortnose suckers at the Sprague River Dam fish ladder, Oregon—Annual Report 2000, in monitoring of Lost River and shortnose suckers in the Upper Klamath Basin, 2001, Annual report of research to the Bureau of Reclamation, 19 p., Contract \# 00AA200049.

Tyler, T.J., Ellsworth, C.M., VanderKooi, S.P., and Shively, R.S., 2007, Riverine movement of adult Lost River, shortnose, and Klamath largescale suckers in the Williamson and Sprague Rivers, Oregon, Annual Report 2004: Annual report of research to the Bureau of Reclamation, $29 \mathrm{p}$.

U.S. Fish and Wildlife Service, 2008, Biological/conference opinion regarding the effects of the U.S. Bureau of Reclamation's proposed 10-year operation plan (April 1, 2008 - March 31, 2018) for the Klamath Project and its effects on the endangered Lost River and shortnose suckers, April 2, 2008: Klamath Falls, Oregon. 


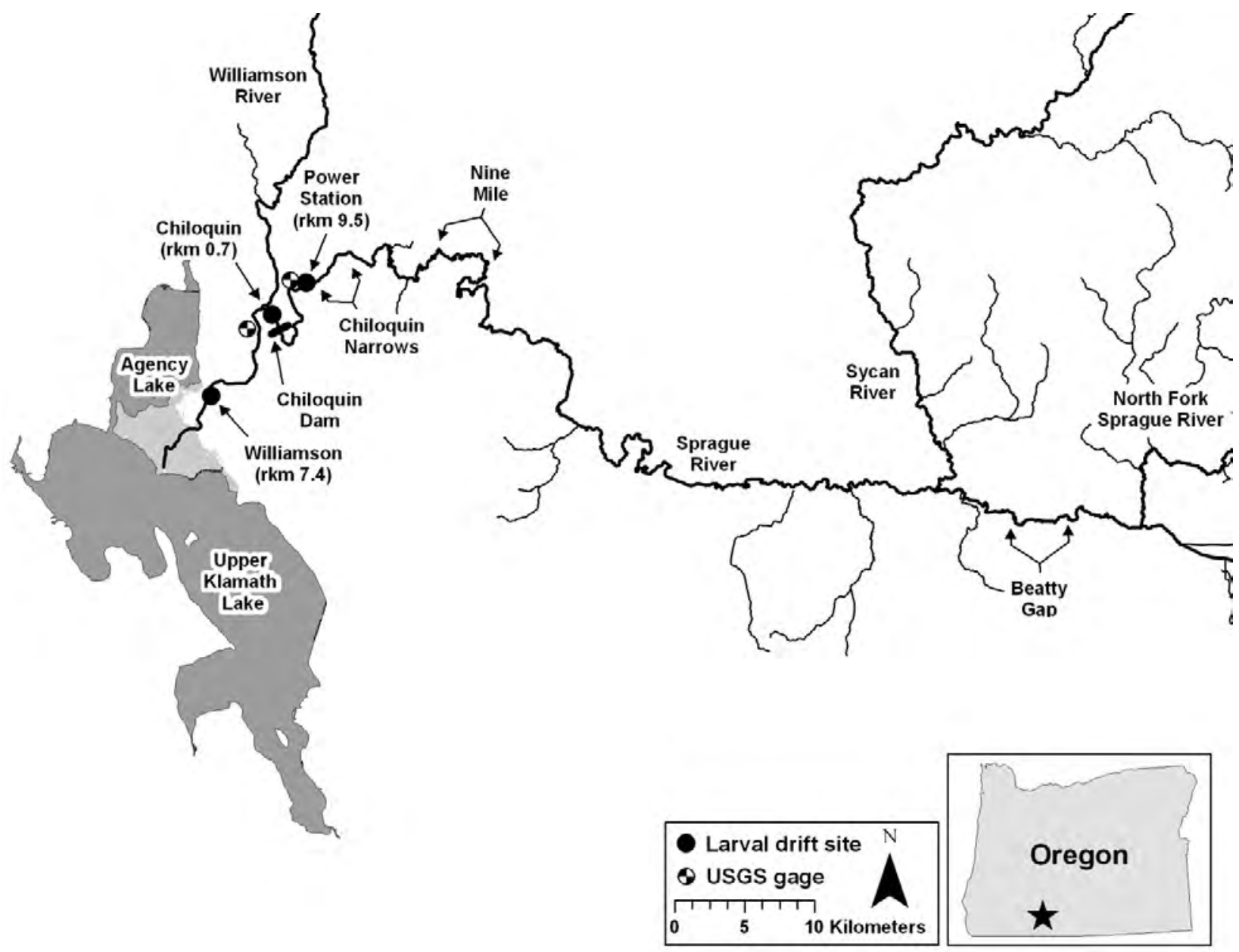

Figure 1. Map of the study area showing larval sucker sampling sites used in 2007 and 2008 to assess larval drift patterns of Lost River and shortnose suckers in the Sprague and Williamson Rivers, Oregon, prior to removal of Chiloquin Dam. 

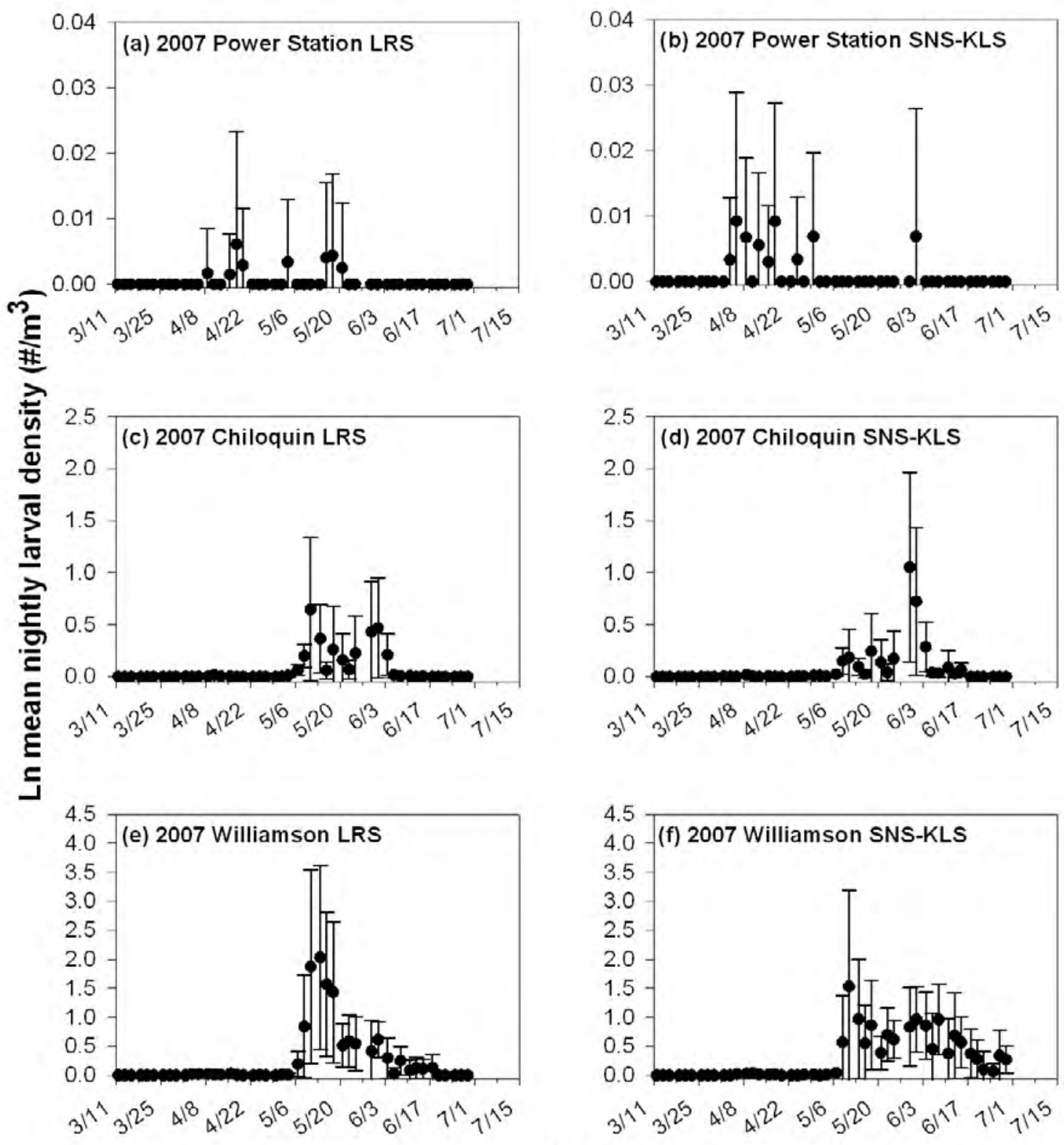

\section{Date}

Figure 2. Natural log transformed nightly $( \pm \mathrm{SD}$ ) mean density of Lost River sucker (LRS) and shortnose sucker or Klamath largescale (SNS-KLS) larvae at (a) Power Station, (b) Chiloquin, and (c) Williamson sampling sites in 2007. Shortnose and Klamath largescale suckers are grouped because larvae of these species cannot be morphologically differentiated. Site locations are shown in figure 1. Note changes in scale for the $y$-axis among figures. 

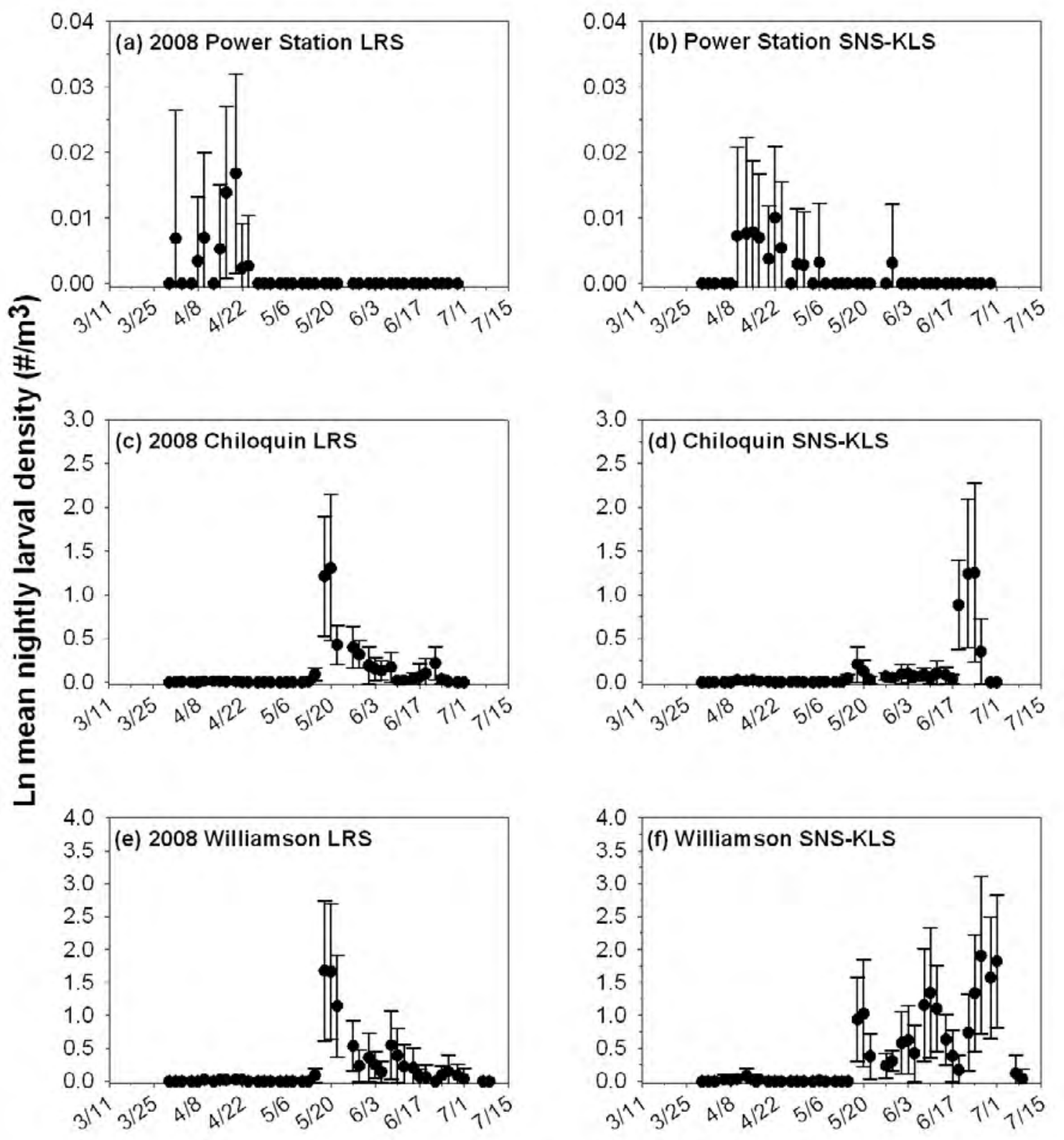

Date

Figure 3. Natural log transformed nightly $( \pm \mathrm{SD}$ ) mean density of Lost River sucker (LRS) and shortnose sucker or Klamath largescale (SNS-KLS) larvae at Power Station (a), Chiloquin (b), and Williamson (c) sampling sites in 2008. Shortnose and Klamath largescale suckers are grouped because larvae of these species cannot be morphologically differentiated. Site locations are shown in figure 1. Note changes in scale for the $y$-axis among figures. 

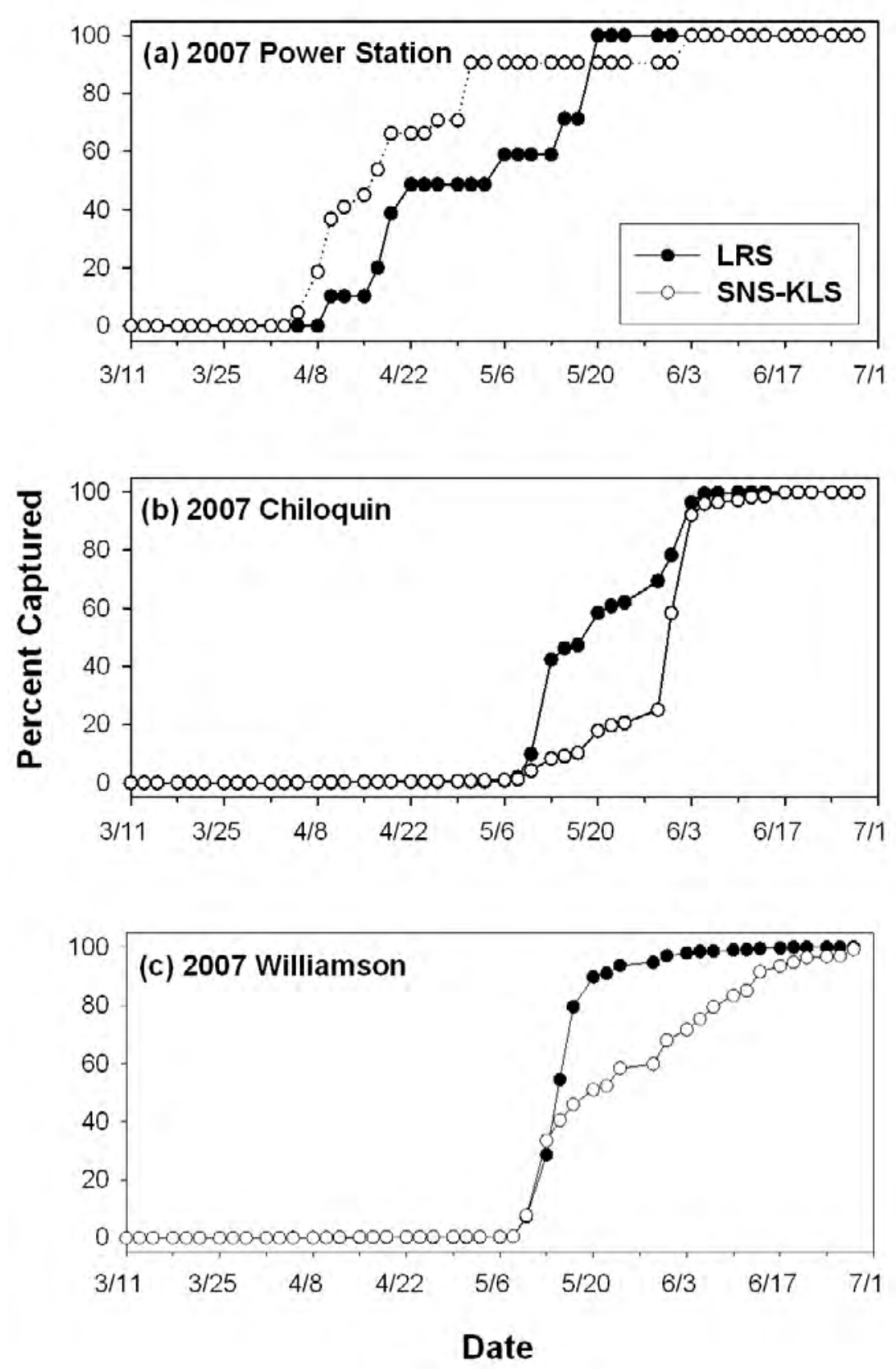

Figure 4. Cumulative proportion of shortnose and Klamath largescale sucker (SNS-KLS) and Lost River sucker (LRS) larvae captured at (a) Power Station, (b) Chiloquin, and (c) Williamson sampling sites by date in 2007. Shortnose and Klamath largescale suckers are grouped because larvae of these species cannot be morphologically differentiated. Site locations are shown in figure 1. 

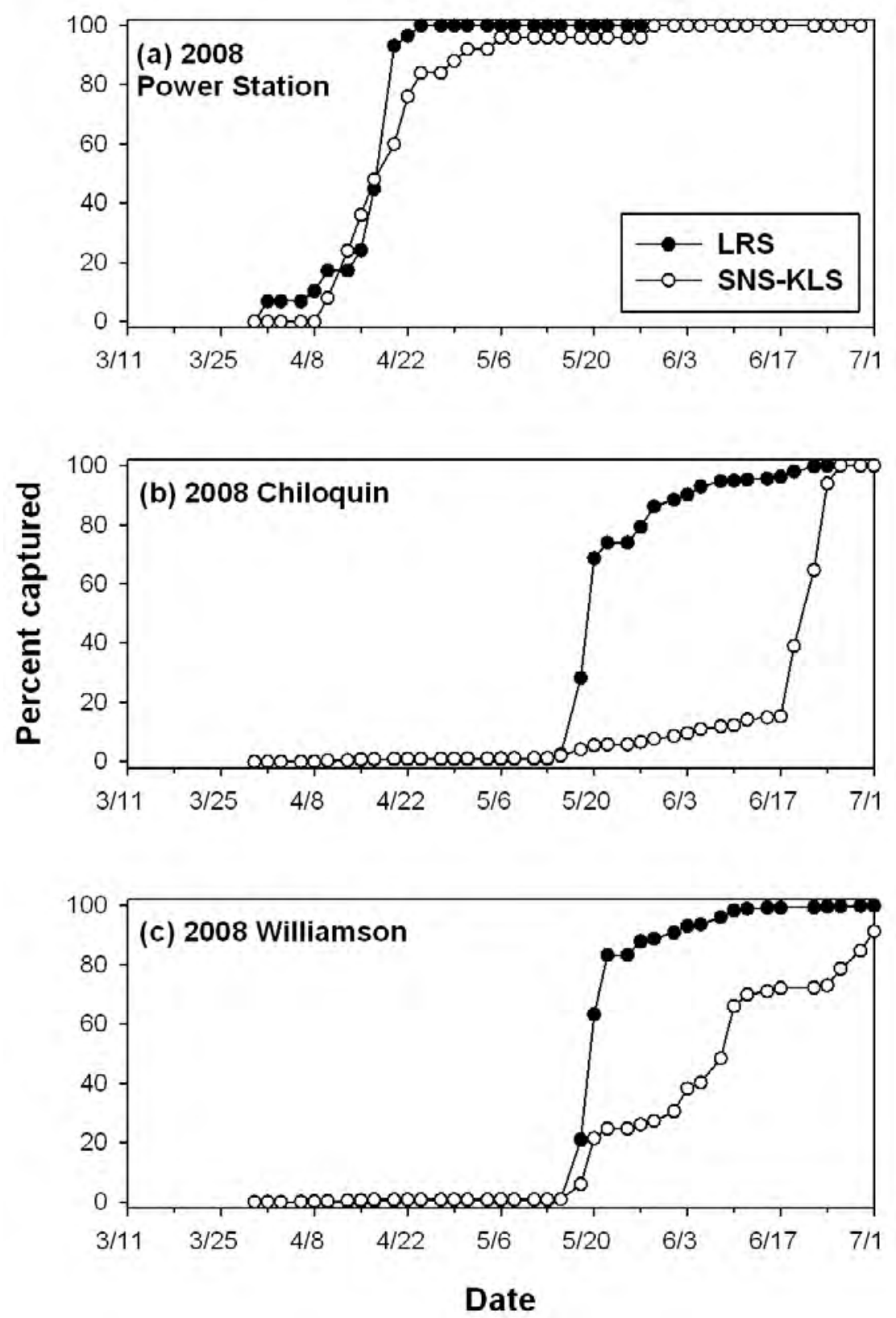

Figure 5. Cumulative proportion of shortnose and Klamath largescale sucker (SNS-KLS) and Lost River sucker (LRS) larvae captured at (a) Power Station, (b) Chiloquin, and (c) Williamson sampling sites by date in 2008. Shortnose and Klamath largescale suckers are grouped because larvae of these species cannot be morphologically differentiated. Site locations are shown in figure 1. 


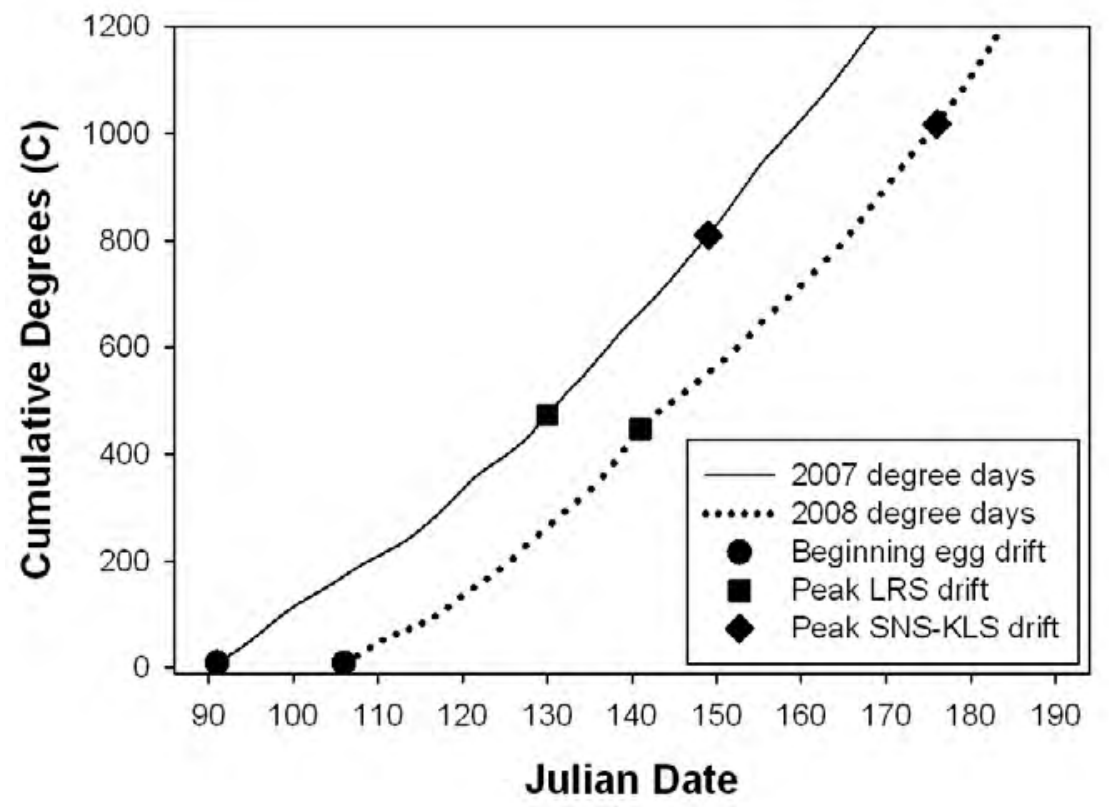

Figure 6. Cumulative degrees calculated from the mean daily temperature of the Sprague River near Chiloquin, OR beginning with the first detection of sucker eggs in the drift at Chiloquin sampling site by Julian date in 2007 and 2008. Dates of beginning sucker egg drift as well as peak catches for Lost River sucker (LRS) and shortnose and Klamath largescale sucker (SNS-KLS) larvae are indicated. Shortnose and Klamath largescale suckers are grouped because larvae of these species cannot be morphologically differentiated. Site locations are shown in figure 1. 

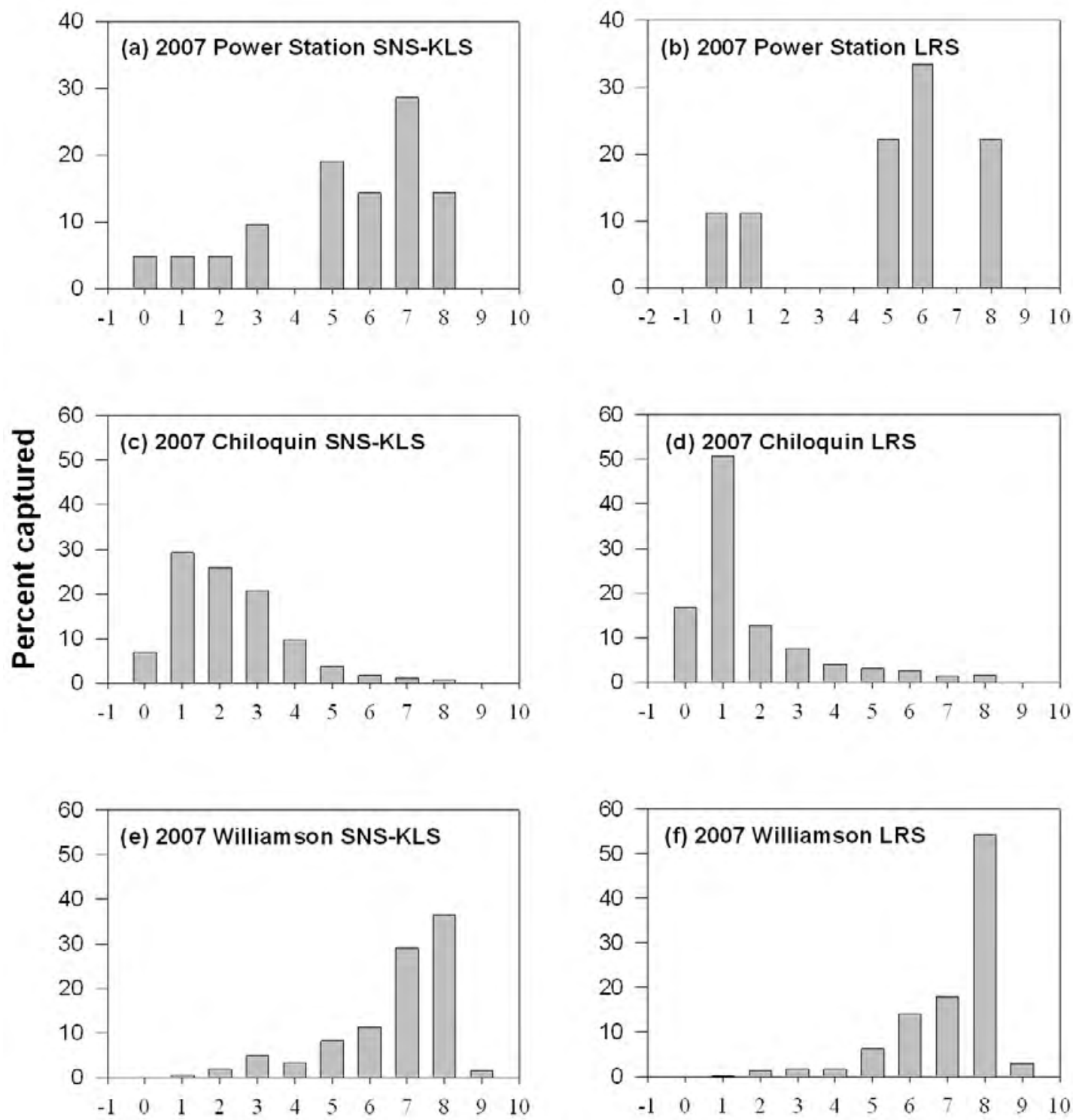

\section{Hours after sunset}

Figure 7. Proportion of shortnose and Klamath largescale sucker (SNS-KLS) and Lost River sucker (LRS) larvae capture by sample hour at Power Station, Chiloquin, and Williamson sampling sites in 2007. Shortnose and Klamath largescale suckers are grouped because larvae of these species cannot be morphologically differentiated. Site locations are shown in figure 1. 

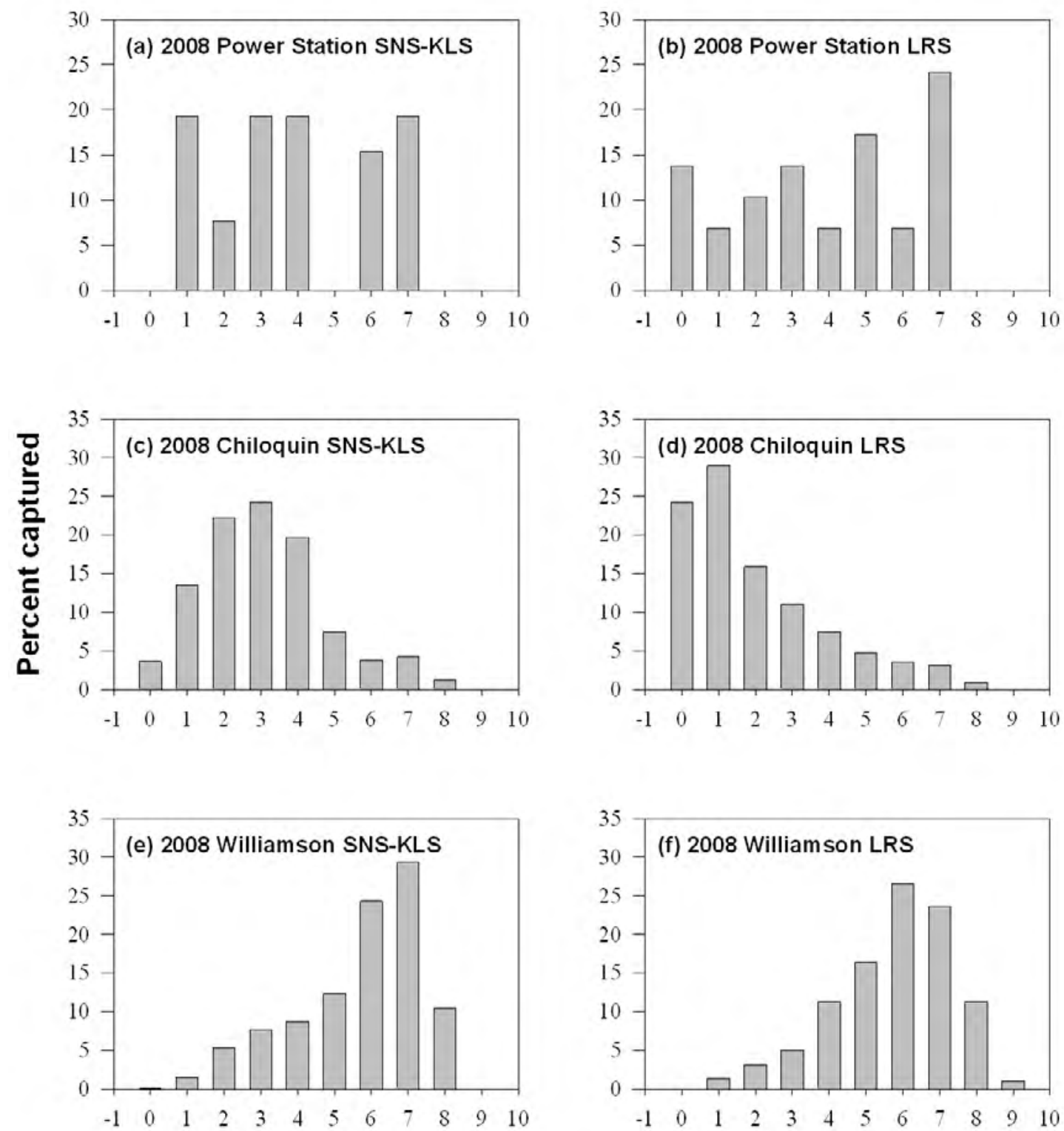

\section{Hours after sunset}

Figure 8. Proportion of shortnose and Klamath largescale sucker (SNS-KLS) and Lost River sucker (LRS) larvae capture by sample hour at Power Station, Chiloquin, and Williamson sampling sites in 2008. Shortnose and Klamath largescale suckers are grouped because larvae of these species cannot be morphologically differentiated. Site locations are shown in figure 1. 


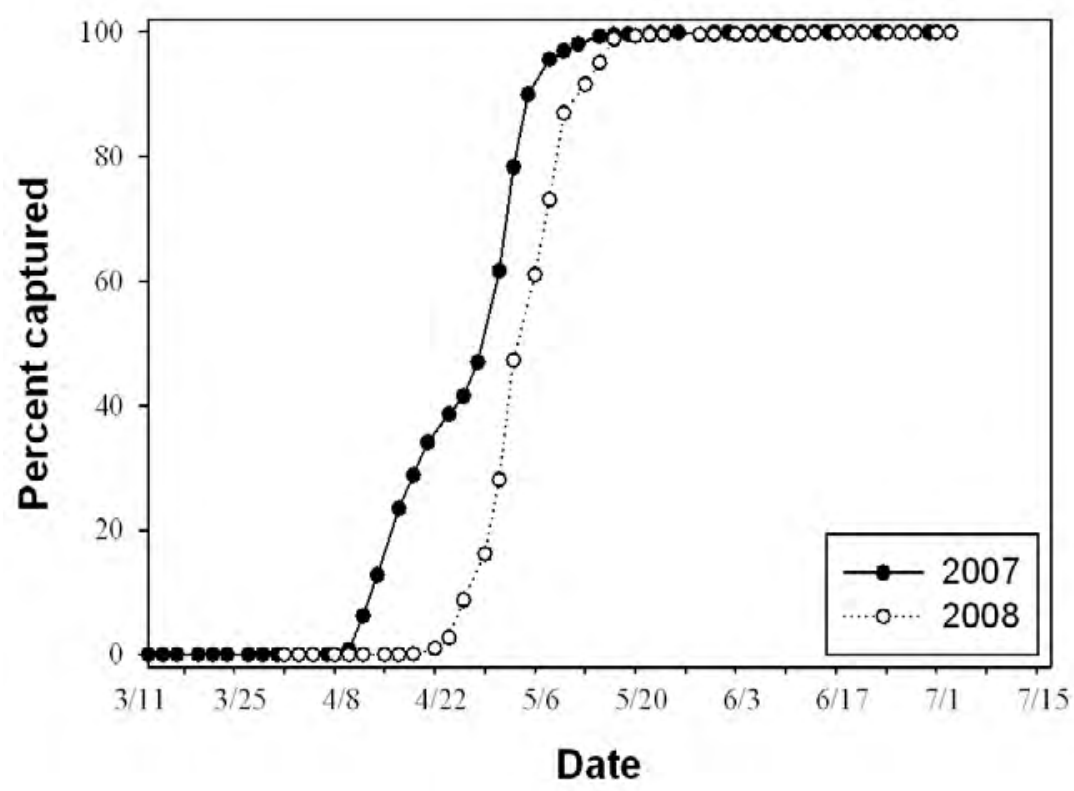

Figure 9. Cumulative percentages of sucker eggs collected at Chiloquin sampling site by date in 2007 and 2008. Site location is shown in figure 1. 

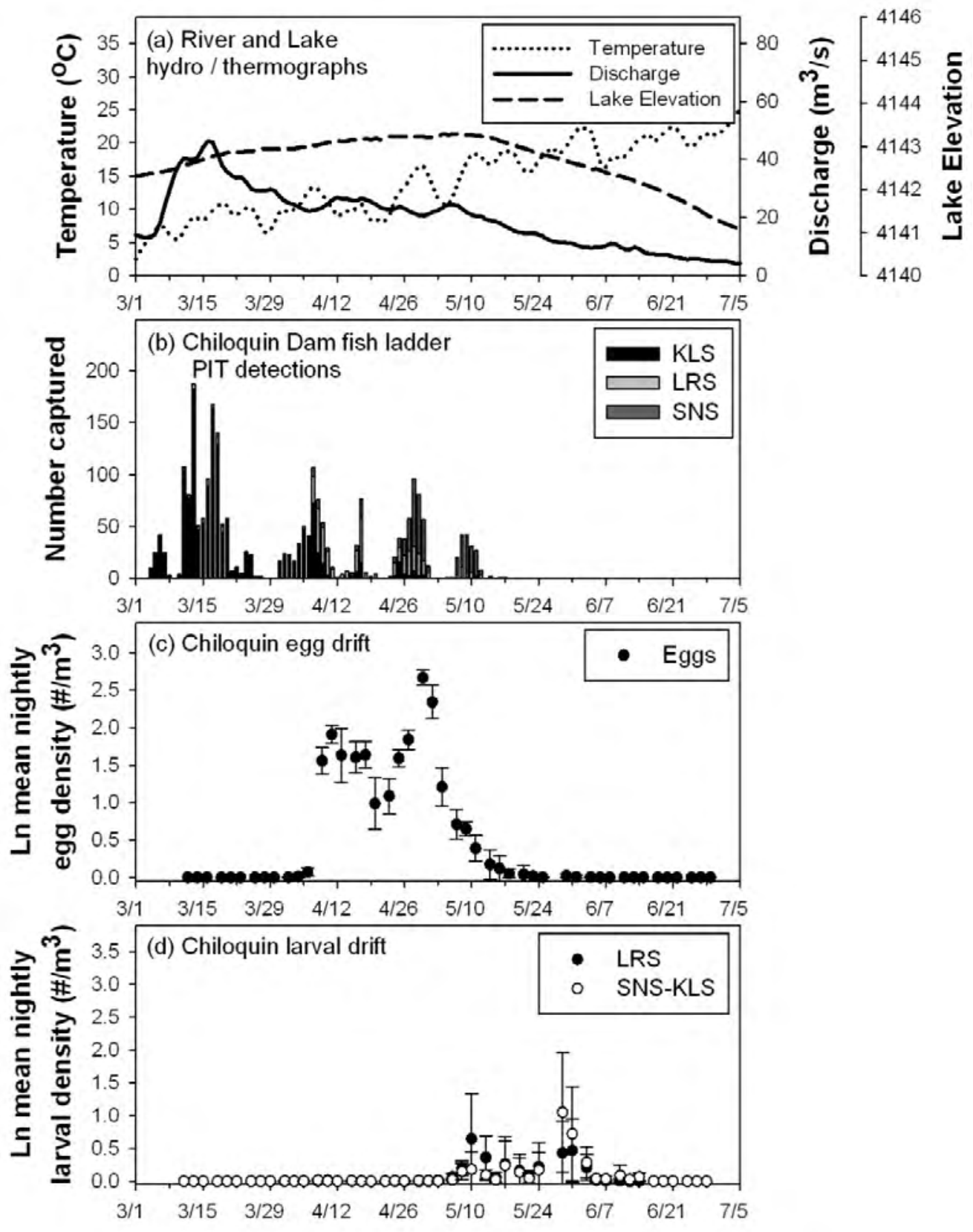

Date

Figure 10. Sprague River temperature $\left(\mathrm{C}^{\circ}\right)$ and discharge $\left(\mathrm{m}^{3} / \mathrm{s}\right)$ and Upper Klamath Lake elevation (ft; a), date of passage or detection of passive integrated transponder (PIT) tagged adult Klamath largescale (KLS), Lost River sucker (LRS), and shortnose sucker (SNS) past the Chiloquin Dam on the Sprague River (b; U.S. Geological Survey, unpub. data, 2007), and natural transformed mean nightly egg and larval densities at Chiloquin sampling site (c and d) in 2007. Larval shortnose and Klamath largescale suckers are grouped because larvae of these species cannot be morphologically differentiated. Site location is shown in figure 1. 

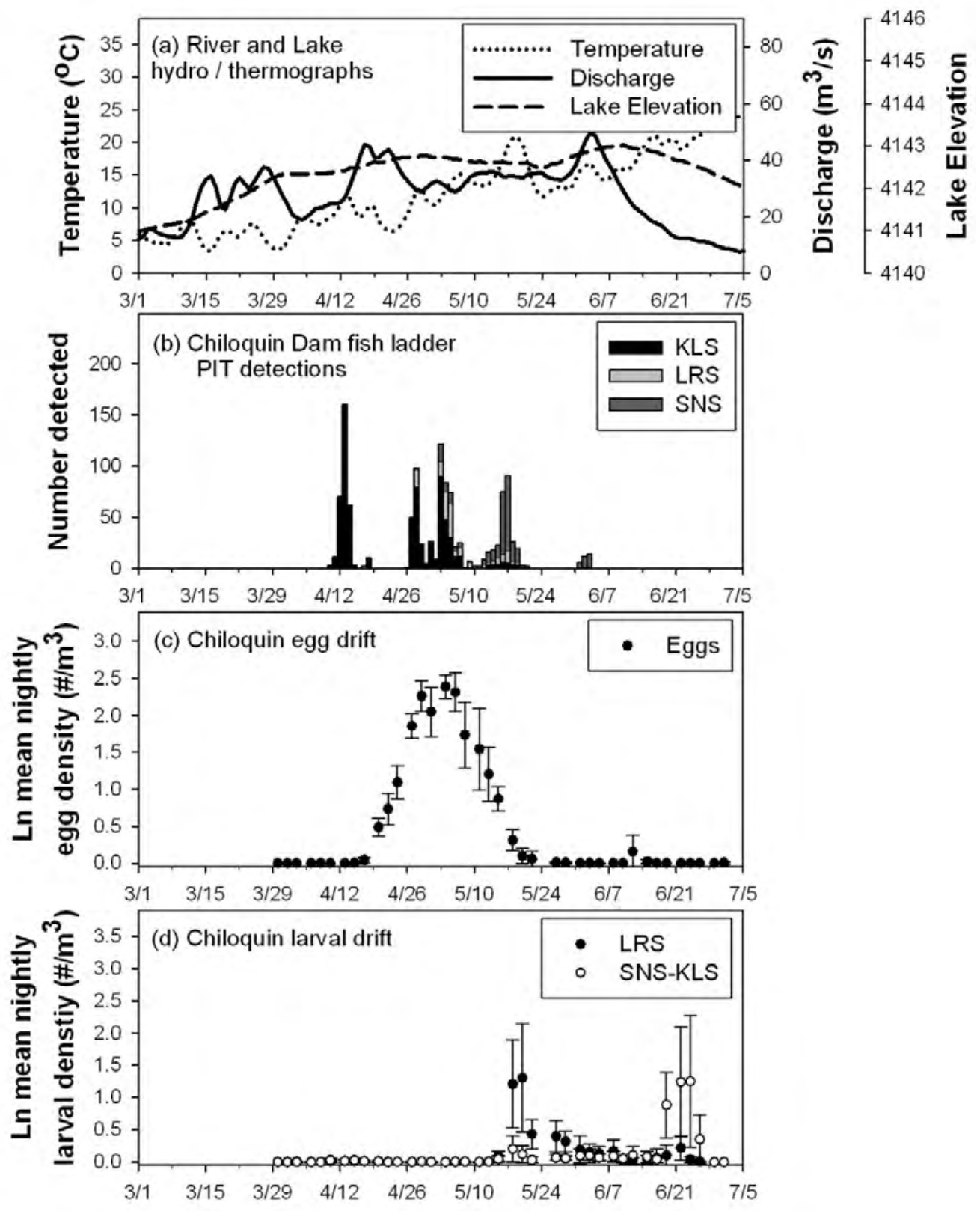

Date

Figure 11. Sprague River temperature $\left(\mathrm{C}^{\circ}\right)$ and discharge $\left(\mathrm{m}^{3} / \mathrm{s}\right)$ and Upper Klamath Lake elevation (ft; a), date of passage or detection of adult passive integrated transponder tagged Klamath largescale (KLS), Lost River sucker (LRS), and shortnose sucker (SNS) past the Chiloquin Dam on the Sprague River (b; Janney and others, 2009), and natural transformed mean nightly egg and larval densities at Chiloquin sampling site ( $c$ and d) in 2008. Larval shortnose and Klamath largescale suckers are grouped because larvae of these species cannot be morphologically differentiated. Site location is shown in figure 1. 


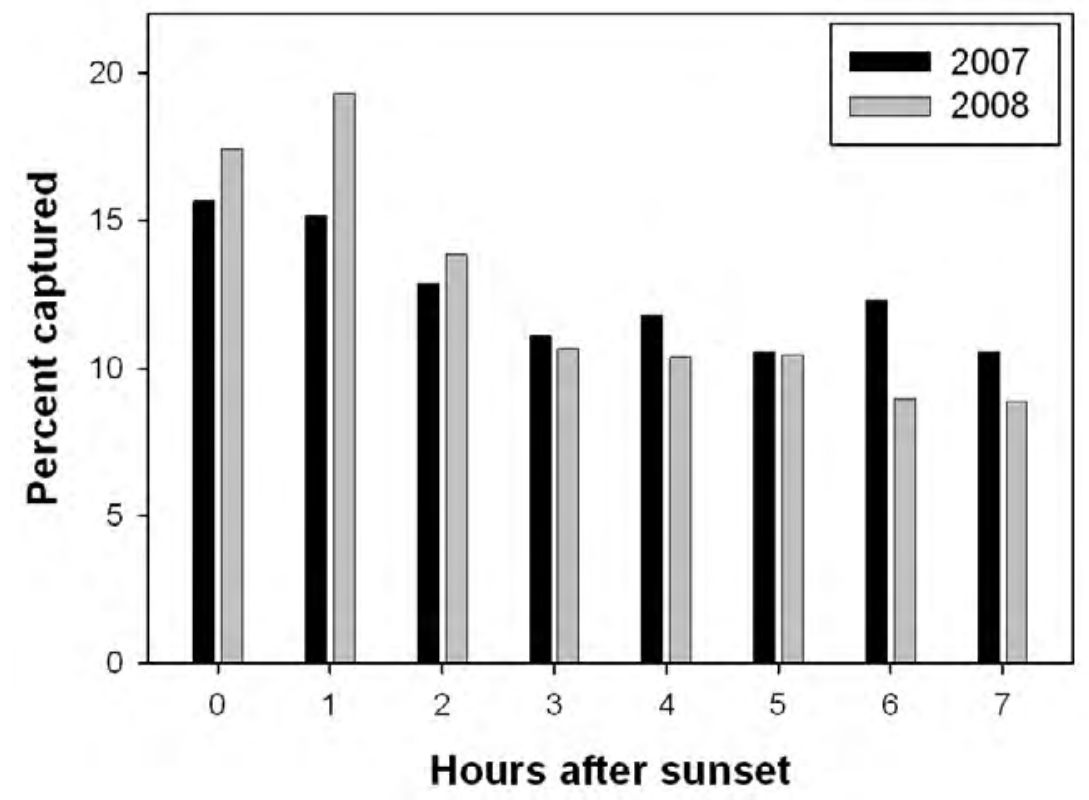

Figure 12. Proportions of sucker eggs collected in the drift by sample hour for the first seven hours after sunset at Chiloquin sampling site in 2007 and 2008. Site location is shown in figure 1. 
Table 1. Total number of samples collected and number of sampling events for the period between the first and last capture, including zero catches, of shortnose and Klamath largescale sucker (SNS-KLS), Lost River sucker (LRS), and unidentified sucker (UIS) larvae in the Sprague and Williamson Rivers in 2007 and 2008.

[Shortnose and Klamath largescale suckers are grouped because larvae of these species cannot be morphologically differentiated. Unidentified sucker larvae had intermediate identifying characteristics or were damaged and therefore were not classified as a particular species. Site locations are shown in figure 1]

\begin{tabular}{lccccc}
\hline & & & \multicolumn{3}{c}{$\begin{array}{c}\text { Number of samples collected between first and } \\
\text { last capture at each site }\end{array}$} \\
\cline { 4 - 6 } Site & Year & $\begin{array}{c}\text { Total number of samples } \\
\text { collected at each site }\end{array}$ & SNS-KLS & LRS & UIS \\
\hline \multirow{3}{*}{ Power Station } & 2007 & 509 & 256 & 355 & 355 \\
& 2008 & 410 & 211 & 109 & 279 \\
Chiloquin & 2007 & 546 & 367 & 434 & 393 \\
& 2008 & 438 & 399 & 397 & 362 \\
Williamson & 2007 & 534 & & & \\
& 2008 & 503 & 412 & 426 & 402 \\
\hline
\end{tabular}

Table 2. Sampling schedule for larval drift sample sites in 2007 and 2008.

[First and last sample values indicate hours after sunset while the interval value indicates the time, in hours, between samples]

\begin{tabular}{lccc}
\hline \multicolumn{1}{c}{ Site } & First sample & Last sample & Interval \\
\hline Power Station & -0.5 & 7.5 & $0.5-1.0$ \\
Chiloquin & -0.5 & 7.5 & $0.5-1.0$ \\
Williamson & 0.0 & 8.0 & $0.5-1.0$ \\
\hline
\end{tabular}


Table 3. Mean larval densities (larvae/ $\mathrm{m}^{3}$ ) for drift samples collected during the period between the first and last capture of shortnose and Klamath largescale sucker (SNS-KLS), Lost River sucker (LRS), and unidentified sucker (UIS) larvae at sites on the Sprague and Williamson Rivers in 2007.

[Shortnose and Klamath largescale suckers are grouped because larvae of these species cannot be morphologically differentiated. Unidentified sucker larvae had intermediate identifying characteristics and therefore were not classified as a particular species. Site locations are shown in figure 1]

\begin{tabular}{lcccc}
\hline Site & Sample year & SNS-KLS & LRS & UIS \\
\hline \multirow{2}{*}{ Power Station } & 2007 & & & \\
& 2008 & 0.002 & 0.004 & 0.001 \\
& & & 0.006 & 0.005 \\
Chiloquin & 2007 & 0.226 & 0.418 & 0.055 \\
& 2008 & 0.321 & 0.248 & 0.118 \\
Williamson & & & \\
& 2007 & 1.001 & 2.790 & 0.240 \\
& 2008 & 1.552 & 0.764 & 0.636 \\
\hline
\end{tabular}


Table 4. Date, hour, and density (larvae/ $\mathrm{m}^{3}$ ) of peak catches of shortnose and Klamath largescale sucker (SNS-KLS) larvae and Lost River sucker (LRS) larvae at sample sites on the Sprague and Williamson Rivers in 2007 and 2008.

[Shortnose and Klamath largescale suckers are grouped because larvae of these species cannot be morphologically differentiated. Site locations are shown in figure 1]

\begin{tabular}{|c|c|c|c|c|c|c|c|}
\hline \multirow[b]{2}{*}{ Site } & \multirow[b]{2}{*}{ Taxa } & \multicolumn{3}{|c|}{2007} & \multicolumn{3}{|c|}{2008} \\
\hline & & Date & $\begin{array}{c}\text { Hours after } \\
\text { sunset }\end{array}$ & $\begin{array}{c}\text { Peak larvae } \\
\text { density }\end{array}$ & Date & Hours after sunset & $\begin{array}{c}\text { Peak larvae } \\
\text { density }\end{array}$ \\
\hline \multirow{2}{*}{ Power Station } & SNS-KLS & April 29 & 0.0 & 0.06 & April 13 & 2.0 & 0.05 \\
\hline & LRS & April 18 & 5.5 & 0.05 & April 1 & 3.0 & 0.06 \\
\hline \multirow{2}{*}{ Chiloquin } & SNS-KLS & May 29 & 1.5 & 9.16 & June 24 & 2.5 & 13.62 \\
\hline & LRS & May 10 & 0.5 & 10.49 & May 20 & 0.5 & 9.90 \\
\hline \multirow{2}{*}{ Williamson } & SNS-KLS & May 11 & 6.5 & 52.28 & June 27 & 6.0 & 38.44 \\
\hline & LRS & May 14 & 7.5 & 108.20 & May 21 & 6.0 & 26.60 \\
\hline
\end{tabular}


Table 5. Growth stages for shortnose and Klamath largescale sucker (SNS-KLS), Lost River sucker (LRS), and unidentified sucker (UIS) captured in the Williamson and Sprague Rivers in 2007 and 2008.

[Shortnose and Klamath largescale suckers are grouped because larvae of these species cannot be morphologically differentiated. Unidentified sucker larvae had intermediate identifying characteristics and therefore were not classified as a particular species. Larvae categorized with undetermined growth stage were typically damaged in a way that prevented the determination of growth stage. Site locations are shown in figure 1]

\begin{tabular}{|c|c|c|c|c|c|c|c|c|c|c|c|}
\hline \multirow[b]{2}{*}{ Site } & \multirow[b]{2}{*}{ Taxa } & \multicolumn{5}{|c|}{2007} & \multicolumn{5}{|c|}{2008} \\
\hline & & $\begin{array}{c}\text { Pre- } \\
\text { flexion }\end{array}$ & Flexion & $\begin{array}{l}\text { Post- } \\
\text { flexion }\end{array}$ & $\begin{array}{c}\text { Undeter- } \\
\text { mined }\end{array}$ & Juvenile & $\begin{array}{c}\text { Pre- } \\
\text { flexion }\end{array}$ & Flexion & $\begin{array}{l}\text { Post- } \\
\text { flexion }\end{array}$ & $\begin{array}{c}\text { Undeter- } \\
\text { mined }\end{array}$ & Juvenile \\
\hline \multirow{3}{*}{$\begin{array}{l}\text { Power } \\
\text { Station }\end{array}$} & SNS-KLS & 0 & 0 & 0 & 21 & 0 & 0 & 11 & 0 & 0 & 1 \\
\hline & LRS & 0 & 0 & 0 & 9 & 0 & 0 & 93 & 4 & 0 & 0 \\
\hline & UIS & 0 & 0 & 0 & 9 & 0 & 1 & 3 & 1 & 3 & 6 \\
\hline \multirow{3}{*}{ Chiloquin } & SNS-KLS & 365 & 3,424 & 10 & 53 & 8 & 32 & 2,164 & 4 & 1 & 50 \\
\hline & LRS & 559 & 3,435 & 8 & 12 & 0 & 73 & 2,636 & 5 & 1 & 69 \\
\hline & UIS & 409 & 227 & 32 & 571 & 0 & 230 & 270 & 0 & 116 & 69 \\
\hline \multirow{3}{*}{ Williamson } & SNS-KLS & 177 & 2,541 & 18 & 1 & 0 & 42 & 2,455 & 1 & 25 & 0 \\
\hline & LRS & 535 & 4,864 & 18 & 5 & 0 & 0 & 1,869 & 3 & 0 & 0 \\
\hline & UIS & 294 & 290 & 2 & 137 & 0 & 26 & 103 & 1 & 68 & 4 \\
\hline
\end{tabular}


Table 6. Median standard length and the number of larvae $<9.0 \mathrm{~mm}$ and juveniles $>14.5 \mathrm{~mm}$ collected for shortnose and Klamath largescale sucker (SNS-KLS), Lost River sucker (LRS), and unidentified sucker (UIS) captured in 2007 and 2008.

[Shortnose and Klamath largescale suckers are grouped because larvae of these species cannot be morphologically differentiated. Unidentified sucker larvae had intermediate identifying characteristics, thus were not classified as a particular species. Site locations are shown in figure 1]

\begin{tabular}{|c|c|c|c|c|c|c|c|}
\hline \multirow[b]{2}{*}{ Site } & \multirow[b]{2}{*}{ Taxa } & \multicolumn{3}{|c|}{2007} & \multicolumn{3}{|c|}{2008} \\
\hline & & Median & $<9.0 \mathrm{~mm}$ & $>14.5 \mathrm{~mm}$ & Median & $<9.0 \mathrm{~mm}$ & $>14.5 \mathrm{~mm}$ \\
\hline \multirow{3}{*}{$\begin{array}{l}\text { Power } \\
\text { Station }\end{array}$} & SNS-KLS & 13.0 & 0 & 0 & 12.7 & 0 & 1 \\
\hline & LRS & 12.4 & 0 & 0 & 12.2 & 0 & 0 \\
\hline & UIS & 12.6 & 0 & 2 & 13.9 & 0 & 7 \\
\hline \multirow{3}{*}{ Chiloquin } & SNS-KLS & 12.1 & 0 & 9 & 11.1 & 0 & 51 \\
\hline & LRS & 12.1 & 0 & 0 & 11.2 & 5 & 70 \\
\hline & UIS & 11.6 & 58 & 33 & 11.2 & 54 & 68 \\
\hline \multirow{3}{*}{ Williamson } & SNS-KLS & 12.2 & 0 & 1 & 11.2 & 0 & 1 \\
\hline & LRS & 12.1 & 0 & 0 & 11.4 & 0 & 0 \\
\hline & UIS & 12.1 & 2 & 0 & 12.1 & 0 & 4 \\
\hline
\end{tabular}

Table 7. Total number of sucker eggs, average egg densities (eggs/ $\mathrm{m}^{3}$ ), and peak egg densities (eggs/ $\mathrm{m}^{3}$ ) for all sucker species combined for the period between the first and last capture, including zero catches, in 2007 and 2008.

[Site locations are shown in figure 1]

\begin{tabular}{lcccc}
\hline \multicolumn{1}{c}{ Site } & Sample year & Total eggs & Average density & Peak density \\
\hline \multirow{2}{*}{ Power Station } & 2007 & & & \\
& 2008 & 1 & $<0.001$ & 0.06 \\
\multirow{2}{*}{ Chiloquin } & 2007 & 44,307 & $<0.001$ & 0.02 \\
& 2008 & 40,347 & 1.216 & 16.71 \\
\multirow{2}{*}{ Williamson } & 2007 & 6 & 1.384 & 17.26 \\
& 2008 & 13 & $<0.001$ & 0.26 \\
& & & 0.002 & 1.22 \\
\hline
\end{tabular}


Publishing support provided by the U.S. Geological Survey

Publishing Network, Tacoma Publishing Service Center

For more information concerning the research in this report, contact the Director, Western Fisheries Research Center U.S. Geological Survey

6505 NE 65th Street

Seattle, Washington 98115

http://wfrc.usgs.gov/ 

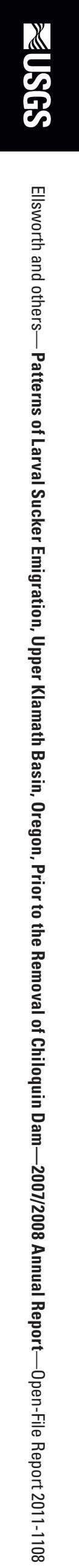